\title{
LIBERTY

August 2012

\section{Abuse of the Journalist's Shield: A State-By-State Survey of \\ Blogger Liability for Trade Secret Misappropriation and Texas's Shield Statutes As A Model for Federal Preemption}

Dustin T. Gaines

Follow this and additional works at: https://digitalcommons.liberty.edu/lu_law_review

\section{Recommended Citation}

Gaines, Dustin T. (2012) "Abuse of the Journalist's Shield: A State-By-State Survey of Blogger Liability for Trade Secret Misappropriation and Texas's Shield Statutes As A Model for Federal Preemption," Liberty University Law Review: Vol. 7 : Iss. 1 , Article 5.

Available at: https://digitalcommons.liberty.edu/lu_law_review/vol7/iss1/5

This Article is brought to you for free and open access by the Liberty University School of Law at Scholars Crossing. It has been accepted for inclusion in Liberty University Law Review by an authorized editor of Scholars Crossing. For more information, please contact scholarlycommunications@liberty.edu. 


\title{
COMMENT
}

\section{ABUSE OF THE JOURNALIST'S SHIELD: A STATE-BY- STATE SURVEY OF BLOGGER LIABILITY FOR TRADE SECRET MISAPPROPRIATION AND TEXAS'S SHIELD STATUTES AS A MODEL FOR FEDERAL PREEMPTION}

\author{
Dustin T. Gaines ${ }^{\dagger}$
}

\section{INTRODUCTION}

On August 11, 2011, after over seventeen months of investigation, the District Attorney of San Mateo County, California, finally charged two defendants in the case of the missing iPhone. ${ }^{1}$ That day, the most newsworthy detail that was revealed was not who was charged, but who was not. $^{2}$ In its press release, San Mateo County announced that it was charging two individuals, Sage Wallower and Brian Hogan, for selling an unreleased

$\dagger$ Editor-in-Chief, Liberty University LAW Review, Volume 7. J.D. Candidate, Liberty University School of Law (2013); B.A., Pensacola Christian College (2004). I would like to thank my Lord and Savior Jesus Christ for His enabling grace-it is to Him that I give all honor and glory. I would also like to thank my beautiful wife Shannon, who is equally responsible for all of my accomplishments in life. Without her help and support, my law school career would not have been possible. Finally, I would like to thank all of the dedicated students on the Liberty University Law Review for their time and effort-especially Mr. Daniel Schmid, whose mentorship not only helped me with this Comment, but also helped me to become a better writer and editor.

1. Press Release, Stephen M. Wagstaffe, District Attorney of the County of San Mateo, District Attorney Announces Filing Decision on Misappropriation of iPhone (Aug. 10, 2011) (on file with author).

The San Mateo County District Attorney's Office has filed misdemeanor charges against two individuals for the misappropriation of an iPhone 4 prototype that was lost by an Apple employee and subsequently recovered in a Redwood City establishment by the defendants on March 25, 2010. Brian Hogan . . . was charged with one count of misappropriation of lost property, and Sage Wallower ... was charged with misappropriation of lost property, and possession of stolen property. . . After a consideration of all of the evidence, it Id. was determined that no charges would be filed against employees of Gizmodo.

2. Sarah J. Purewal, Gizmodo Not Charged in Apple iPhone 4 Prototype Purchase, PC WORLD (Aug. 11, 2011, 7:05 AM), http://www.pcworld.com/article/237853/gizmodo_not_ charged_in_apple_iphone_4_prototype_purchase.html. 
iPhone 4 prototype to Gizmodo.com, ${ }^{3}$ but it did not bring charges against Gizmodo.com or any of its employees for broadcasting pictures and video footage of the highly secret iPhone 4 prototype months before its scheduled release. ${ }^{4}$

Wallower and Hogan's crimes began in March of 2010 at a restaurant in Redwood City, California. That evening, Gray Powell, a software engineer for Apple, went to Gourmet Haus Staudt, ${ }^{5}$ a San Francisco area restaurant, to celebrate his birthday. Powell's personal iPhone was different from the iPhone commercially available at that time. Powell was using an Apple prototype - the not-yet released iPhone $4 .^{6}$ Apple was set to release this model of iPhone on June 24, 2010.' When Powell left the restaurant that evening, his carelessness led to the story that would dominate the news in both tech blogs and traditional news outlets for weeks. ${ }^{8}$ When he left the restaurant that evening, Powell accidentally left the iPhone prototype on his bar stool. ${ }^{9}$ After he left, Hogan and Wallower found the phone and noticed that there was something different about Powell's iPhone. ${ }^{10}$ Apple, recognizing the public's interest in its unreleased products, took the precautionary measure of constructing the exterior of the prototype to resemble the exterior of the iPhone 3GS, which was the latest iPhone available to consumers at that time. ${ }^{11}$ Despite Apple's precautionary measures, Wallower and Hogan noticed that there were several subtle differences on Powell's phone. ${ }^{12}$

3. About Gizmodo, GizmoDo, http://gizmodo.com/about/ (play the video) (last visited Sept. 17, 2012). Gizmodo.com is an online technology website and blog that reviews new technology and reports on any news within the world of emerging technology. Id.

4. Id.

5. Aff. for Search Warrant at 2-3, Apr. 29, 2010 [hereinafter Warrant Affidavit]. This affidavit supports California's request for a search warrant of the home of Jason Chen, founder of Gizmodo.com.

6. Id.

7. Paul Miller, iPhone 4 Announced, Launching June 24 for $\$ 199$ with New FaceTime Video Chat, ENGADGET (June 7, 2010, 1:35 PM), http://www.engadget.com/2010/06/07/ iphone-4-announced/.

8. Warrant Affidavit, supra note 5 , at 4.

9. Jesus Diaz, How Apple Lost the iPhone 4, Gizmodo (Apr. 19, 2010, 8:10 PM), http://gizmodo.com/5520438/how-apple-lost-the-next-iphone.

10. Id.

11. Warrant Affidavit, supra note 5, at 2.

12. Diaz, supra note 9 , at 2 . 
Wallower and Hogan then discovered that Powell worked for Apple, and they contacted the online technology blog Gizmodo.com. ${ }^{13}$ After hearing that Wallower and Hogan were in possession of an unreleased prototype of Apple's flagship product, Gizmodo purchased the device from Wallower and Hogan for $\$ 5,000 .{ }^{14}$ After acquiring the device, Gizmodo confirmed that this was indeed an unreleased iPhone. ${ }^{15}$ Gizmodo then photographed, recorded video footage of, and closely analyzed the prototype. ${ }^{16}$ Five days later, Gizmodo published its photos, videos, and observations of the prototype iPhone on its website. ${ }^{17}$ Despite the fact that Gizmodo had published this information, it was not charged for any crime or sued civilly. ${ }^{18}$ Instead, Apple formally requested that Gizmodo return the telephone. ${ }^{19}$

Trade secrets are often the most overlooked assets that a corporation may have. ${ }^{20}$ This is partly true because trade secrets often involve many different forms. ${ }^{21}$ While patents must meet specific, statutory requirements, trade secrets may be any business secret from which a company derives economic value. ${ }^{22}$ This is a critical distinction because trade secrets are the only form of intellectual property that may be either tangible or intangible. ${ }^{23}$ Technology news sources, like Gizmodo, recognize that technology companies work very hard to guard the secrecy of unreleased products. Trade secret law makes it possible to protect intellectual property, including intangible property, such as Apple's right to unveil its new technology.

When a website, like Gizmodo, purchases information that it knows is confidential, dissects it, records it on video, and broadcasts it, that website should be held both criminally and civilly liable for the misappropriation of

13. Warrant Affidavit, supra note 5, at 5.

14. Id. at 6.

15. Jason Chen, This Is Apple's Next iPhone, Glzmodo (Apr. 19, 2010, 10:00 AM), http:/gizmodo.com/5520164/this-is-apples-next-iphone.

16. Warrant Affidavit, supra note 5 , at 2 .

17. Id.

18. Press Release, Wagstaffe, supra note 1.

19. Brian Lam, A Letter: Apple Wants Its Secret iPhone Back, Gizmodo (Apr. 19, 2010, 11:50 PM), http://gizmodo.com/5520479/a-letter-apple-wants-its-secret-iphone-back.

20. Henry C. Su, Trade Secrets, in The Intellectual Property Handbook: A Practical Guide for Franchise, Business and IP Counsel 261 (William A. Finklestein \& James R. Simms III eds., 2005) [hereinafter IP Handbook].

21. Id. at 262 .

22. Id. at $262,264$.

23. Id. at 262 . 
the victimized corporation's trade secrets. Some corporations rely heavily on the field-testing of their products to ensure that the products operate in accordance with the intended design. Even though Powell lost the iPhone prototype, an inadvertent mistake of an employee does not grant anyone the authority to willfully publish information that is known to be secret.

Bloggers are not the only threat to owners of trade secrets. Trade secret misappropriation can occur in many factual scenarios. Commonly, a departing employee may leave his company-where he learned and implemented the company's trade secrets-and then begin working for a new company. In other cases, an inventor may present his plan or prototype to a company for review, but, because of the jurisdiction where the alleged misappropriation occurred, the idea may not rise to the level of protection that it would receive in virtually every other state.

There are three dynamics that currently make trade secret law difficult to enforce against those who misappropriate the trade secrets. First, unlike all other forms of intellectual property, trade secrets are civilly enforced under state laws and do not benefit from a uniform, federal system of laws like copyrights, trademarks, and patents. ${ }^{24}$ With the advent of the Internet and modern commerce, business is no longer carried out only on a local scale. It is carried out in a national and international marketplace and should be afforded the standardized, civil protection that all other forms of intellectual property are given. Second, courts today have placed an onerous burden on corporations to establish whether they have adequately guarded their secrets. ${ }^{25}$ Only sufficiently guarded secrets are afforded trade secret status and protection. ${ }^{26}$ Third, the use of the Economic Espionage $\mathrm{Act}^{27}$ has been almost nonexistent since its enactment in $1996{ }^{28}$ Under the Economic Espionage Act, some trade secret infringement claims are actionable as criminal offenses. ${ }^{29}$ In certain bad faith infringement claims, use of the

24. See Economic Espionage Act, 18 U.S.C. $\$ 1831-1839$ (2006). Trade secrets are enforced criminally under the Economic Espionage Act. Id. $\$ 1831,1832$. Under the Act, there is an ancillary provision for civil injunctions that is only invoked when a defendant is convicted of violating the Act. Id. $\$ 1836(\mathrm{a})$. As it stands, there is not a stand-alone provision within the Act that solely provides civil remedies for trade secret misappropriation.

25. See infra Part II.A.6.b.

26. See 18 U.S.C. $\$ 1839(3)(A)(2006)$.

27. Economic Espionage Act, 18 U.S.C. $\$ \$ 1831-1839$ (2006).

28. See supra Part III.C (statistically noting the lack of EEA enforcement for trade secret misappropriation).

29. IP Handbook, supra note 20 , at $316-17$. 
Economic Espionage Act may be the only deterrent to preventing misappropriation of trade secrets.

Therefore, a new system of uniform enforcement is needed and should be established to protect the trade secrets of American businesses. This Comment begins by analyzing the historic context of trade secret protection and both the civil and criminal penalties that may be imposed upon an Internet site for disseminating trade secrets against the owner's wishes. Next, this Comment addresses the historic background of the reporter's shield and compares it with newsgathering crimes. Finally, this Comment proposes (1) that Congress should incorporate civil remedies, such as damages and injunctions, into the Economic Espionage Act to establish uniformity in the national marketplace; (2) that the onerous burden of proving that a company adequately protected its trade secrets should be lessened; and (3) that the criminal component of the revised Economic Espionage Act should be utilized more frequently than it has been since its inception in 1996.

\section{BACKGROUND}

\section{A. Trade Secrets}

\section{Origins of Trade Secret Law}

It is speculated that intellectual property law-specifically trade secret law-is rooted in the laws of the early Roman Empire. ${ }^{30}$ The earliest measures of trade secret protection were rooted in contract, tort, and

30. A. Arthur Schiller, Trade Secrets and the Roman Law; the Actio Servi Corrupti, 30 ColUM. L. REv. 837, 838 (1930). In Roman courts, legal recourse could be taken against a slave who divulged his master's secrets. Id. at 838. The cause of action was in actio servi corrupti, which literally means an "action for corrupting the slave." Id. at 839. Schiller states that in Roman times,

[t]he problem ... can be stated as follows. The employee (slave) of a business man (master) is maliciously enticed by a competitor (third person) to divulge business secrets. The employee thereupon steals secret formulae, plans, lists of customers, and the like, and turns them over to the competitor; or, as a corollary, destroys them at the instigation of the competitor; or he divulges accounts, evidence of the status of the business, or the amount of liabilities and assets; or he falsifies accounts, reports, or other records.

Id. at 838-39 (footnote omitted). Contra Alan Watson, Trade Secrets and Roman Law: The Myth Exploded, 11 Tul. EuR. \& CIV. L.F. 19 (1996) (arguing the contrary position that trade secret law does not date back to the early Roman Empire). 
agency law. ${ }^{31}$ The earliest trade secret cases did not recognize trade secrets as a form of intellectual property. ${ }^{32}$ In these early cases, unlawful trade secret distribution was commonly enforced as a breach of faith, a breach of confidence, or a breach of an explicitly or implicitly mandated duty that an employee owed to his employer. ${ }^{33}$ The first Western case that began to develop current trade secret law was the English case Newbery v. James. ${ }^{34}$ In Newbery, the Lord Chancellor denied the plaintiff's specific performance request because it was impossible to grant an injunction without fully disclosing and making known to the court and, thus, to the general public, the complete details of the trade secret. ${ }^{35}$

More than thirty years before any of the early English cases regarding trade secret law, the framers of the United States Constitution evidenced a profound interest in protecting and upholding intellectual property rights for American citizens. ${ }^{36}$ Article I, section 8, clause 8 of the Constitution grants Congress the power " $[t]$ o promote the Progress of Science and useful Arts, by securing for limited Times to Authors and Inventors the exclusive Right to their respective Writings and Discoveries[.]" ${ }^{\prime \prime 3}$ In the United States, Justice Joseph Story labeled the disclosure of trade secrets as "irreparable mischief," and stated that

courts of equity will restrain a party from making a disclosure of secrets communicated to him in the course of a confidential employment. And it matters not... whether the secrets be

31. See Trade Secrets: Prac. guide $\$ 1.7$ (2011) (Henry H. Perritt, Jr.) (citing Morison v. Moat, (1851) 68 Eng. Rep. 492 (Ch.); 9 Hare 241).

32. See id. (citing Green v. Folgham, (1823) 57 Eng. Rep. 159 (Ch.); 1 Sim. \& St. 398 (holding that a mere verbal secret that has never been committed to writing is not a form of intellectual property and that the best remedy would lie in contract or tort law)).

33. See id. (citing Morison v. Moat, (1851) 68 Eng. Rep. 492 (Ch.); 9 Hare 241); cf. Lehman v. Dow Jones \& Co., 783 F.2d 285, 299 (2d Cir. 1986) (holding that "[a] cause of action may arise with respect to information that does not qualify as a trade secret if the information is disclosed in confidence and later used in a manner that breaches the confidence").

34. See id. (citing Newbery v. James, (1817) 35 Eng. Rep. 1011 (Ch.); 2 Mer. 446).

35. Id.

36. See Edward C. Walterscheid, Conforming the General Welfare Clause and the Intellectual Property Clause, 13 HARV. J.L. \& TECH. 87, 90-91 (1999).

37. U.S. CONST. art. I, $₫ 8, \mathrm{cl} .8$. 
secrets of trade ... or any other secrets of the party important to his interests. ${ }^{38}$

The first American case that recognized this concept of trade secret protection was Vickery v. Welch, ${ }^{39}$ but Peabody v. Norfolk ${ }^{40}$ was the first American case to enforce and protect a trade secret from unauthorized dissemination. ${ }^{41}$ In Peabody, the court recognized that

if [a man] invents or discovers, and keeps secret, a process of manufacture...he has a property in it, which a court of chancery will protect against one who in ... breach of confidence undertakes to apply it to his own use, or to disclose it to third persons. ${ }^{42}$

The Peabody court's analysis of what constitutes a trade secret, what a trade secret owner must do to protect it, and what constitutes a breach of confidence, laid the foundation for modern trade secret law. ${ }^{43}$

Trade secret protection is enforced in both the civil and criminal realms. ${ }^{44}$ In the civil realm, the available remedies for misappropriation of a trade secret are compensatory damages, punitive damages, and injunctions. ${ }^{45}$ In the criminal realm, both state-specific legislation and the Economic Espionage Act of 1996 (EEA) ${ }^{46}$ govern criminal trade secret enforcement. $^{47}$ Violations under the EEA are felony offenses that are punishable by time served in prison or monetary fines. ${ }^{48}$

38. 2 JOSEPH STORY, COMMENTARIES ON EQUITY JURISPRUDENCE AS ADMINISTERED IN ENGLAND AND AMERICA $\$ 952$ (12th ed. 1877) (footnote omitted).

39. Vickery v. Welch, 36 Mass. 523, 523 (1837) (holding that in a contractual agreement between parties, a party's promise not to disseminate a trade secret is valuable consideration).

40. 98 Mass. 452 (1868).

41. Id. at 458 .

42. Id.

43. See Trade Secrets: Prac. guide $\$ 1.7$ (2011) (Henry H. Perritt, Jr.).

44. IP Handbook, supra note 20 , at 319.

45. Id. at 305.

46. Economic Espionage Act, 18 U.S.C. $\$ 1831-1839$ (2006).

47. IP Handbook, supra note 20 , at 316-17.

48. Id. at 317 . 


\section{Relationships to Other Forms of Intellectual Property Law}

A patent protects the physical exploration or embodiment of an idea, ${ }^{49} \mathrm{a}$ copyright protects an expression, ${ }^{50}$ and a trade secret indirectly protects both. ${ }^{51}$ When corporation is deciding how to best protect its intellectual property, each form of property protection has advantages and disadvantages that vary based upon the purpose of the desired protection. ${ }^{52}$

a. Patent law

Patents and trade secrets are the most closely-related fields within the realm of intellectual property. ${ }^{53}$ Both patent and trade secret laws seek to protect the owners of intellectual property, but the laws seek to do so in different ways. ${ }^{54} \mathrm{~A}$ degree of confusion can arise in this area because all patents are eligible to be protected as trade secrets, but not all trade secrets are eligible to be protected as patents. ${ }^{55}$

The first major-and most important-distinction between trade secrets and patents is that patents are inherently public, while trade secrets are inherently confidential. ${ }^{56}$ To qualify for a patent, the applicant must file his patent application publicly and disclose all of the details of the invention that he seeks to protect. ${ }^{57}$ Under 35 U.S.C. $\$ 112$, Congress mandated that a patent application include a "written description of the invention, and of the manner and process of making and using it, in such full, clear, concise, and exact terms as to enable any person skilled in the art... to make and

49. See 35 U.S.C. $\$ 101-103(2006)$.

50. See 17 U.S.C. $\$ 102(2006)$.

51. See infra pp. 94-97. (defining how intellectual property may be eligible for trade secret, copyright, or patent protection).

52. See infra pp. 94-99. (discussing the advantages and disadvantages of trade secret, copyright, or patent protection).

53. See Kewanee Oil Co. v. Bicron Corp., 416 U.S. 470, 480-81 (1974) (discussing the interface between federal patent policy and state trade secret regulation).

54. IP Handbook, supra note 20, at 237-38.

55. Kewanee Oil Co., 416 U.S. at 494 (Marshall, J., concurring) (recognizing that the duration of trade secrets is superior to that of patents).

56. See 35 U.S.C. $\$ 112$ (2006). Patent applicants must disclose all of the details and diagrams of their invention to the United States Patent and Trademark Office when applying for a patent. Id. But $c f$. RESTATEMENT (THIRD) OF UNFAIR COMPETITION: DEFINITION OF TRADE SECRET $\$ 39$ (1995) ("A trade secret is any information that can be used in the operation of a business or other enterprise and that is sufficiently valuable and secret to afford an actual or potential economic advantage over others." (emphasis added)).

57. 35 U.S.C. $\$ 112(2006)$. 
use the same ...." ${ }^{m 8}$ Alternatively, for a trade secret to be protected, the burden is on the owner of the confidential property to take reasonable measures to conceal the property from the general public. ${ }^{59}$

The second major distinction between patents and trade secrets is their eligibility requirements. ${ }^{60} \mathrm{~A}$ trade secret may be any form of informationboth tangible and intangible-so long as it derives economic value to its owner. ${ }^{61}$ Patents, however, must satisfy heightened, technical requirements based upon their substantive, proprietary value. ${ }^{62}$ Congress established the proprietary value requirements of patents in 35 U.S.C. $\$ 101$, which mandates that a patent meet the requirements of (1) utility, ${ }^{63}(2)$ the proper subject matter, ${ }^{64}(3)$ novelty, ${ }^{65}$ and (4) non-obviousness. ${ }^{66}$ First, the patent applicant can establish utility by demonstrating that the invention is useful and new. ${ }^{67}$ The standard for utility is not a difficult standard to satisfy and only requires that the invention will provide some practical use that is not illegal or "mischievous." requirements, a patent applicant must show that the object is a "process, machine, manufacture, or composition of matter." ${ }^{\prime 69}$ Under the novelty requirement, a patent applicant must demonstrate that his invention is merely something new and different from other, existing inventions. ${ }^{70}$ To be

\section{Id.}

59. 18 U.S.C. $\$ 1839(3)(A)$ (2006) (stating that under the Economic Espionage Act, a trade secret owner must take "reasonable measures" to ensure that the property has been adequately concealed); $c f$. RESTATEMENT (ThiRD) OF UNFAIR COMPETITION: DEFINITION OF TRADE SECRET $\$ 39 \mathrm{cmt}$. f. (1995) (stating that information, to qualify for trade secret protection, must be kept secret by its owner to the extent it would be difficult or costly for others to acquire it).

60. See 35 U.S.C. $\$ 101-112$ (2006) (setting forth the eligibility requirements for the patentability of inventions).

61. See 18 U.S.C. $\$ 1839(3)(A)$ (2006); see also RESTATEMENT (THIRD) OF UNFAIR COMPETition: Definition of TRAde Secret $\$ 39 \mathrm{cmt}$. e (1995).

62. See 35 U.S.C. $\$ 101,112$ (2006). The term "proprietary" is defined as "relating to, or holding as property." BLACK's LAW DICTIONARY 1339 (9th ed. 2011).

63. 35 U.S.C. $\$ 101(2006)$.

64. See id.

65. Id. $\$ 102$.

66. Id. $\$ 103$.

67. Graham v. John Deere Co., 383 U.S. 1, 6 (1966).

68. Bedford v. Hunt, 3 F. Cas. 37, 37 (Cir. Ct. Mass. 1817).

69. 35 U.S.C. $\$ 101$ (2006).

70. 35 U.S.C. $\$ 102(2006)$. 
non-obvious, a patent applicant must demonstrate that the invention is more than a mere aggregation of old parts which perform or produce no new or different function. ${ }^{71}$ In other words, the proposed use must have some sort of an "inventive step" 72 that differentiates it from the obvious or ordinary use of an invention currently used by the public. ${ }^{73}$

The third major distinction between patents and trade secrets is the duration of time each protection affords.$^{74}$ When a patent is granted, the patentee is given a monopoly over the rights of the patent for twenty years from the date the patent application was filed. ${ }^{75}$ Additionally, under patent protection, the patentee is given an absolute monopoly over the protected rights of his property. ${ }^{76}$ When the patent term expires, however, the patentee loses all rights to his invention, and the public is entitled to the same use of the patented information that the patentee held for the duration of the patent term. ${ }^{77}$ Alternatively, the duration of a trade secret runs in perpetuity until the owner reveals the protected secret. ${ }^{78}$

In Kewanee Oil Co. v. Bicron Corp., the Supreme Court discussed the distinction between trade secret protection and patent protection. ${ }^{79}$ The Court divided the intellectual property into the categories of (1) clearly unpatentable, (2) doubtfully patentable, and (3) clearly patentable. ${ }^{80}$ The Court reasoned that property that is clearly unpatentable or doubtfully patentable is an excellent candidate for trade secret protection because it may easily meet all of the requirements of a trade secret. ${ }^{81}$ As for property

71. Great Atl. \& Pac. Tea Co. v. Supermarket Equip. Corp., 340 U.S. 147, 152 (1950).

72. 37 C.F.R. $\$ 1.484$ (2008).

73. See 35 U.S.C. $\$ 103(2006)$.

74. Compare 35 U.S.C. $\$ 154$ (a)(2) (2006), with IP Handbook, supra note 20, at 282 exhibit 6-1 (noting the differences in the duration of time between patent and trade secret protections).

75. 35 U.S.C. $\$ 154(\mathrm{a})(2)$.

76. IP Handbook, supra note 20, at 230.

77. See 35 U.S.C. $\$ 154(a)(1)$.

78. See Kewanee Oil Co. v. Bicron Corp., 416 U.S. 470, 496 (1974) (Douglas, J., dissenting). Trade secrets are more vulnerable to not having a guaranteed duration of protection because "trade secret law ... does not offer protection against discovery by fair and honest means, such as by independent invention, accidental disclosure, or by so-called reverse engineering." Id. at 476.

79. Id. at 489.

80. Id. at 484 .

81. Id. at 484-90. 
that is clearly patentable, the Court noted that the owner of the property retains the right to choose between trade secret and patent protection. ${ }^{82}$

As for property that is eligible for both patent and trade secret protection, the owner's decision as to which protection to utilize will vary based upon his purposes for the property. ${ }^{83}$ One such consideration is whether the proprietary character of the protected property is easily reverse engineered. ${ }^{84}$ If it is easily reverse engineered, then the trade secret owner is better served by receiving a patent on the protected property because the secret will be disclosed through honest means. ${ }^{85}$ Another consideration is the likelihood that the property will be publicly sold and distributed or used privately. ${ }^{86}$ For information that is to be used privately, trade secret protection is a superior alternative to patent protection because no facts are ever disclosed, and the secret remains with its owner in perpetuity. To determine which protection to utilize, the owner must undertake a risk analysis to determine which measure would best serve his products and their needs ${ }^{87}$ In regard to property that is clearly patentable, the Kewanee Oil Court stated that "[w]here patent law acts as a barrier, trade secret law functions relatively as a sieve." ${ }^{\text {88 }}$

\section{b. Copyright law}

A copyright exists in original works of authorship that are fixed in any tangible medium of expression. ${ }^{89}$ As with patents, there is an inherent tension between copyrights and trade secrets because both may be used to protect intellectual property. ${ }^{90}$ To be eligible for both a copyright and a

82. Id. at 491.

83. Id.

84. Id. at 490 .

85. Id. at 476 .

86. Id. at $483,491$.

87. 2 Louis altman \& Malla Pollack, Callmann on Unfair Competition, TRademarks AND MONOPOlies $\$ 14.1$ : Theories of Protection (4th ed. 2006).

88. Kewanee Oil Co., 416 U.S. at 490 . The Court noted that a patent holder is guaranteed an absolute protection barrier that blocks a third party from independently developing and using the same subject matter for a fixed duration of time. Trade secret protection, on the other hand, does not provide a barrier from the independent development of a third party and only provides protection so long as the patent holder meets his burden of keeping the trade secret undisclosed to the general public. Id.; see also Alan Devlin, Restricting Experimental Use, 32 HaRV. J.L. \& PUB. POL'Y 599, 628 (2009).

89. 17 U.S.C. $\$ 102(a)(2006)$.

90. IP Handbook, supra note 20 , at 284 . 
trade secret, the owner of the property must affix the property within some form of tangible expression; i.e., it must be capable of being seen or heard. ${ }^{91}$ Copyright owners are granted the sole rights of reproducing, distributing, displaying, and making derivative works or translations of the work, but copyright protection does not block a third party from independently developing and using the same subject matter. ${ }^{92}$

There are several differences and similarities between trade secrets and copyrights. First, the term of a trade secret lasts in perpetuity, whereas a copyright protects information for seventy years after the death of its creator. ${ }^{93}$ Second, a copyright is created at the moment the idea is fixed into a tangible medium of expression, whereas a trade secret is created at the moment that its owner derives some economic value from it and has taken the reasonable measures necessary to preserve the confidentiality of it. ${ }^{94}$ Third, like trade secrets, there are no proprietary character standards or requirements for a copyright, and the owner is not required to register it. ${ }^{95}$ In certain circumstances, a copyright holder may register his copyright with the United States Copyright Office, but this is not mandatory to enforce the protection of the copyrighted material. ${ }^{96}$ The decision of whether to seek copyright protection or trade secret protection ultimately comes down to the nature of the information and its principal use. ${ }^{97}$ In circumstances where the owner wishes to keep information confidential and believes that it is possible to do so, trade secret protection should be chosen over copyright or patent protection. ${ }^{98}$

91. 17 U.S.C. $\$ 102(a)(2006)$.

92. Id. $\$ 106$.

93. Id. $\$ 302$.

94. Id. $\$ 102$.

95. Id. $\$ 104(\mathrm{a})$.

96. See id. $\$ 408(\mathrm{a})$; see also id. $\$ 411$ (explaining the registration benefits that are procured through the registration process); id. $\$ 501$ (b) (stating that the provisions for infringement of a copyright are limited to parties who registered under $\$ 411$ ); id. $\$ 505$ (stating that the attorney's fees and costs are recoverable in any civil action). Although copyright registration is not mandatory, it makes provision for the plaintiff to claim legal fees and increased damage amounts. IP Handbook, supra note 20, at 192.

97. AltMAN \& POLLACK, supra note $87, \$ 14.14$.

98. Id. 


\section{Trade Secret Protection}

Trade secrets are often the most undervalued asset that a corporation may have. ${ }^{99}$ This is partly true because-unlike copyrights, trademarks, and patents-trade secrets are not publicly filed; thus, they are often overlooked and forgotten. ${ }^{100}$ Without a public filing requirement, both state and federal laws effectively allow intangible ideas to fall under the umbrella of trade secret protection. ${ }^{101}$ However difficult a trade secret may be to inventory and ascertain, a corporation must nevertheless take the necessary measures to protect trade secrets against unlawful dissemination. ${ }^{102}$ The following subsections provide the definitional elements of trade secrets, ${ }^{103}$ the steps that must be taken by a corporation to preserve a trade secret's confidential status, ${ }^{104}$ and what must be proved to enforce trade secret misappropriation. ${ }^{105}$

\section{Criminal Liability-Economic Espionage Act of 1996}

The main arm of criminal enforcement for the unlawful dissemination of trade secrets is the EEA. ${ }^{106}$ Congress explicitly stated that the primary purpose of the EEA is not to punish employees who change employers or start their own private business while using general knowledge and skills developed while employed. ${ }^{107}$ Rather, Congress's intent was to criminalize a former employee's use of knowledge about "specific products or processes" that are unique to a company against that company-the former employer. ${ }^{108}$ Under the EEA, violators of trade secret dissemination may face monetary penalties, jail time, probation, or some combination of these forms of punishment. ${ }^{109}$

99. See IP Handbook, supra note 20, at 261; see also Palmer \& Cay, Inc. v. Marsh \& McLennan Co., 404 F.3d 1297, 1301 n.8 (11th Cir. 2005).

100. See IP Handbook, supra note 20 , at 261.

101. Id. at 262 .

102. Id.

103. See infra Part II.A.6.a-c.

104. See infra Part I1.A.6.b.

105. See infra Part II.A.7-8.

106. See IP Handbook, supra note 20 , at 317.

107. H.R. REP. No. 104-788, at 7 (1996), reprinted in 1996 U.S.C.C.A.N. 4021, 4026 [hereinafter Congressional Report].

108. Id.

109. Id. at 3-4. 


\section{History of the EEA}

On October 11, 1996, President Clinton signed the EEA into law. ${ }^{110}$ The President stated that the purpose of the EEA was to "help us crack down on acts like software piracy... that cost American businesses billions of dollars.... And it will advance our national security."111 The EEA is governed by 18 U.S.C. $\$ 1831-1839$ and provides two primary causes of action. ${ }^{12}$ First, 18 U.S.C. $\$ 1831$ (a) imposes criminal sanctions on an individual who intentionally or knowingly disseminates a trade secret that is to the benefit of a foreign power. ${ }^{113}$ It was Congress's intent to leave "benefit" to be interpreted broadly by the courts. ${ }^{14}$ Congress expressly stated that "'benefit' means not only an economic benefit but also a reputational, strategic, or tactical benefit." ${ }^{115}$ Since the EEA's inception in 1996 , there have been few convictions under 18 U.S.C. $\$ 1831 .{ }^{116}$ Violation of this section constitutes the crime of economic espionage under the EEA. ${ }^{117}$ Second, 18 U.S.C. $\$ 1832$ criminalizes domestic theft of trade secrets "related to or included in a product that is produced for or placed in interstate or foreign commerce." ${ }^{118}$ Under the EEA, any person convicted

110. Press Release, Office of the Press Secretary, The White House, President on Economic Espionage Act Signing (Oct. 11, 1996), 1996 WL 584924.

111. Id.

112. 18 U.S.C. $\$ 1831-1839$ (2006).

113. Economic Espionage Act, 18 U.S.C. $\$ 1831$ (a) (2006) (stating that " $[w]$ hoever, intending or knowing that the offense will benefit any foreign government... knowingly...steals, or without authorization appropriates... a trade secret ... shall ... be fined ... or imprisoned ... or both.").

114. Congressional Report, supra note 107, at 11.

115. Id.

116. See infra Part III.C (statistically noting the EEA's lack of use for prosecuting trade secret theft).

117. 18 U.S.C. $\$ 1831$ (2006).

118. Economic Espionage Act: Theft Of Trade Secrets, 18 U.S.C. $\$ 1832(a)$ (2006). This statute states that

[w] hoever, with intent to convert a trade secret, that is related to or included in a product that is produced for or placed in interstate ... commerce, to the economic benefit of anyone other than the owner thereof, and intending or knowing that the offense will, injure any owner of that trade secret, knowingly -

(1) steals, or without authorization appropriates ... such information ....

Id.

shall ... be fined ... or imprisoned ... or both. 
for any act of unlawful dissemination ${ }^{119}$ of a corporation's trade secrets will face a monetary fine of up to $\$ 5,000,000$, a prison sentence of up to ten years for each violation he is convicted of, or both a prison sentence and a fine. ${ }^{120} \mathrm{~A}$ person convicted under this section of the EEA is convicted of the crime of "Theft of Trade Secrets."

During the first five years of the EEA, either the Attorney General, the Deputy Attorney General, or the Assistant Attorney General for the Criminal Division of the Department of Justice were required to approve any prosecution for violation of the EEA. ${ }^{122}$ The rationale behind this approval requirement was to ensure that each case brought under the EEA was not a purely civil matter. ${ }^{123}$ Today, the Attorney General has dropped the approval requirement for prosecutions under 18 U.S.C. $\$ 1832$, but has kept the approval requirement in place for the foreign affairs provisions of 18 U.S.C. $\$ 1831 .{ }^{124}$

\section{EEA Definition of a Trade Secret}

The Uniform Trade Secret Act of 1985 provides the most widely used definition of what comprises a trade secret under both the EEA and the common law. ${ }^{125}$ Eighteen U.S.C. $\$ 1839(3)$ provides both the definition of a trade secret under the EEA and the necessary elements that must be proved for a defendant to be convicted under the EEA. ${ }^{26}$ Congress derived the term "trade secret" primarily from the definition used in the Uniform Trade Secrets Act (UTSA). ${ }^{127}$ In 18 U.S.C. $\$ 1839(3)$, Congress established that

119. See infra Part II.A.7-8 (defining "unlawful dissemination" and explaining the EEA's treatment of it).

120. See 18 U.S.C. $\$ 1832$ (a)(5), (b) (2006).

121. Id. $\$ 1832$.

122. David J. Loundy, Computer Crime, Information Warfare, ANd Economic ESPIONAGE 543 (2003).

123. Id.

124. Id.

125. See UnIform Trade SeCrets ACT WITH 1985 AMENDMENTS $\$ 1(4)$ (1985).

126. See 18 U.S.C. $\$ 1839$ (2006).

127. See Uniform Trade Secrets ACt with 1985 Amendments $\$ 1$ (1985) (stating that "a 'trade secret' means all forms and types of financial, business, scientific, technical, economic, or engineering information"); see also Congressional Report, supra note 107, at 12. Congress has established that a secret may only reach the status of a "trade secret" when the trade secret derives independent, economic value through its confidentiality and that the owner has taken reasonable steps to protect it. Id. 
(3) the term "trade secret" means all forms and types of financial, business, scientific, technical, economic, or engineering information, including patterns, plans, compilations, program devices, formulas, designs, prototypes, methods, techniques, processes, procedures, programs, or codes, whether tangible or intangible, and whether or how stored, compiled, or memorialized physically, electronically, graphically, photographically, or in writing if -

(A) the owner thereof has taken reasonable measures to keep such information secret; and

(B) the information derives independent economic value, actual or potential, from not being generally known to, and not being readily ascertainable through proper means by, the public.... ${ }^{128}$

\section{a. Information}

Under the EEA, there are two broad categories of trade secrets that are eligible for enforcement and protection. ${ }^{129}$ These two categories are defined in 18 U.S.C. $\$ 1839$ as business information and technical information. ${ }^{130}$ First, business information is general information that is unique to the owner and used within his business; some examples include customer lists, financial information, or any confidential work product that is produced by the business. ${ }^{131}$ Second, technical information is information that is

128. 18 U.S.C. $\$ 1839(3)$ (2006) (emphasis added).

129. See id.

130. 18 U.S.C. $\$ 1839(3)$ states, that a trade secret can be all "types of financial, business, scientific, technical, economic, or engineering information, including patterns, plans, compilations, program devices, formulas, designs, prototypes, methods, techniques, processes, procedures, programs, or codes, whether tangible or intangible, and whether or how stored, compiled, or memorialized physically, electronically, graphically, photographically, or in writing ...." Id.

131. See, e.g., Roton Barrier, Inc. v. Stanley Works, 79 F.3d 1112, 1117 (Fed. Cir. 1996) (holding that market analysis information constitutes a trade secret); Duncan v. Steuzle, 76 F.3d 1480, 1488 (9th Cir. 1996) (holding that marketing and strategy plans can constitute trade secrets); SI Handling Sys., Inc. v. Heisley, 753 F.2d 1244, 1260 (3d Cir. 1985) (holding that internal cost and pricing analysis information constitutes a trade secret); Am. Express Fin. Advisors, Inc. v. Yantis, 358 F. Supp. 2d 818, 831 (N.D. Iowa 2005) (holding that confidential information about a franchisor's clients and their financial histories and future goals constitutes a trade secret); Frosty Bites, Inc. v. Dippin' Dots, No. 3-01-CV-1532-M, 2003 WL 21196247 , at ${ }^{*}$ (N.D. Tex. May 19, 2003) (holding that manuals relating to the operation of a business franchise constitute a trade secret); Ready Link Healthcare v. Cotton, 
completely unique to the company that owns it; some examples include blueprints to a machine, a secret recipe, computer software codes, engineering notebooks, or the knowledge of a process that a company uses in its manufacturing. ${ }^{132}$ This information is typically derived from intensive labor and investment into the particular field in which the corporation is engaged.

b. Reasonable measures to keep such information secret

To qualify for a trade secret, the trade secret owner must take protective steps to ensure that his trade secret is kept out of the hands of others. ${ }^{133}$ Under the EEA, these measures of protection must meet the standard of reasonableness. ${ }^{134}$ The owner's mere desire to keep information secret is not enough to meet the reasonable protection standard. ${ }^{135}$ Additionally, industry competitors, the public, or others who could utilize the economic value from its disclosure must not generally know the information. ${ }^{136}$ The UTSA states, "If the principal persons who can obtain economic benefit from information are aware of it, there is no trade secret." ${ }^{137}$ Reasonable measures to maintain secrecy have been held to include "advising employees of the existence of a trade secret, limiting access to a trade secret

24 Cal. Rptr. 3d 720, 729 (Cal. Ct. App. 2005) (holding that confidential personnel information such as names of employees, compensation plans for employees, and other miscellaneous employee information constitutes a trade secret).

132. See, e.g., Uncle B's Bakery, Inc. v. O’Rourke, 920 F. Supp 1405, 1429 (N.D. Iowa 1996) (holding that confidential information concerning secret recipes, production planning, and packaging processes constitutes a trade secret); Harbor Software, Inc. v. Applied Sys., Inc., 887 F. Supp. 86, 90 (S.D.N.Y. 1995) (holding that the overall design process and actual design of a software program constitute a trade secret); Integrated Cash Mgmt. Servs., Inc. v. Digital Transactions, Inc., 732 F. Supp. 370, 376 (S.D.N.Y. 1989) (holding that negative information, i.e., failed designs and processes that were learned through trial and error, constitutes a trade secret); Coca-Cola Bottling Co. v. Coca-Cola Co., 107 F.R.D. 288, 289 (D. Del. 1985) (noting that "[t]he complete formula for Coca-Cola is one of the best-kept trade secrets in the world"); Olson v. Nieman's, Ltd., 579 N.W.2d 299, 314 (Iowa 1998) (holding that plans, designs, patterns, and specifications and configurations for specialized equipment to be used in a franchised operation constitute trade secrets).

133. See 18 U.S.C. $\$ 1839(3)$ (A) (2006).

134. Id.

135. IP Handbook, supra note 20 , at 275.

136. Id. at 273 .

137. Uniform Trade SeCrets ACT WITH 1985 AMENDMENTS $\$ 1 \mathrm{cmt}$. at 7 (1985). 
on a 'need to know basis,' requiring employees to sign confidentiality agreements, and keeping secret documents under lock."138

A trade secret may be communicated to a select group of people while still maintaining its status as a trade secret. ${ }^{139}$ This is permissible when the secrets are communicated to others within the company or an independent contractor so long as the parties involved agree to safeguard the information by virtue of a confidentiality agreement. ${ }^{140}$ Currently, no set objective standard exists for the courts to follow to determine whether a corporation's measures of protection rise to the level of reasonableness. ${ }^{141}$ In each case, the courts look to the nature of the trade secret and to the controls that have been established to protect its dissemination. ${ }^{142}$ In Religious Technology Center v. Netcom, ${ }^{143}$ the District Court for the Northern District of California established that in certain circumstances, the reasonableness standard may require a trade secret owner to employ a combination of protective measures to maintain the status of a trade secret. ${ }^{144}$ In addition to any combination of protection employed, courts today have consistently held that some form of a confidentiality agreement is required to ensure that all parties are aware of the confidentiality of the protected information. ${ }^{145}$

\section{c. Derives economic value from not being publicly known}

Not only must the information be kept secret, but the secrecy of the trade secret must cause it to be valuable. ${ }^{146}$ This value is analyzed in terms of speculating what the monetary value of the trade secret is or would be to both the trade secret owner and his competitors. ${ }^{147}$ In Learning Curve Toys

138. Religious Tech. Ctr. v. Netcom On-Line Commc'n Servs., Inc., 923 F. Supp. 1231, 1253 (N.D. Cal. 1995) (citations omitted).

139. IP Handbook, supra note 20 , at 271.

140. Id.

141. Id. at 275 .

142. Id. at $275-76$.

143. Religious Tech. Ctr., 923 F. Supp. at 1253.

144. Id.

145. See Cinebase Software, Inc. v. Media Guar. Trust, Inc., No. C98-1100 FMS, 1998 WL 661465 , at ${ }^{*} 10$ (N.D. Cal. 1998) (holding that a confidentiality agreement may be required to maintain trade secret status).

146. 18 U.S.C. $\$ 1839(3)$ (b) (2006).

147. Learning Curve Toys, Inc. v. Playwood Toys, Inc., 342 F.3d 714, 726 (7th Cir. 2003). The pertinent trade secrets were the methods that were employed in the production of a certain toy train track. $I d$. at 725 . The trade secret made it possible for a toy train to travel 
v. Playwood Toys, ${ }^{148}$ the Seventh Circuit analyzed the economic value component by comparing the sales figures of a toy train track before and after a trade secret was implemented in the manufacturing process of the train track. ${ }^{149}$ The court noted that the sales for the track skyrocketed after the trade secret was implemented and that the sales increase was satisfactory and articulable evidence of the economic value of the toy company's trade secret. ${ }^{150}$

Model jury instructions help define this concept further by explaining that "[i]ndependent economic value ... means financial worth which, when compared to other methods or processes publicly known to those in the same or similar businesses or scientific community, give the holder of method or processes a competitive advantage over others." ${ }^{51}$ The Supreme Court discussed trade secrets in Ruckelshaus v. Monsanto Co. ${ }^{152}$ and emphasized that "the value of a trade secret lies in the competitive advantage it gives its owner over competitors." 153 Apparent from this definition, trade secret law is a means of monetizing the research and development efforts of companies, where the owners do not wish to patent or copyright their discoveries. ${ }^{154}$

\section{Misappropriation Under the EEA}

Under the EEA, a prosecutor may charge a defendant for actual misappropriation or conversion of a trade secret, conspiracy to misappropriate a trade secret, or an attempt to misappropriate a trade secret. ${ }^{155}$ The act includes two statutes under which a defendant may be tried and convicted-one that specifically focuses on misappropriation to foreign governments, and the other, which generally focuses upon theft of trade secrets by a foreign or domestic defendant. ${ }^{156}$ Although each of these

uninhibited on a toy train track, but, due to a special manufacturing process, the train track emitted a sound as the toy train passed by. Id. at 718 .

148. 342 F.3d 714 .

149. Id. at 718,720 .

150. Id. at 718 .

151. Michelle L. Evans, Establishing Liability for Misappropriation of Trade Secrets: $\$ 31$ Independent Economic Value, in 91 AMERICAN JURISPRUDENCE ProOf OF FaCTs 95 (3d ed., 2012) (emphasis added).

152. Ruckelshaus v. Monsanto Co., 467 U.S. 986 (1984).

153. Id. at $1011 \mathrm{n} .15$.

154. IP Handbook, supra note 20, at 270.

155. 18 U.S.C. $\$ 1831-1832$. (2006).

156. See id. $\$ \$ 1831(\mathrm{a}), 1832(\mathrm{a})$. 
sections differs in regard to the scope of the EEA, they essentially possess the same elements that need to be proved to convict a defendant. ${ }^{157}$ The only minor differences between the two statutes are the mens rea requirements in subparts (a) in each section, and scope of the term "trade secret":

18 U.S.C. $\$ 1831$ Economic Espionage

(a) In general.-Whoever, intending or knowing that the offense will benefit any foreign government, foreign instrumentality, or foreign agent, knowingly-

(1) steals ... obtains a trade secret;

(2) without authorization copies ... a trade secret;

(3) receives, buys, or possesses $a$ trade secret ..... ${ }^{158}$
18 U.S.C. $\$ 1832$ - Theft of Trade Secrets

(a) Whoever, with intent to convert a trade secret, that is related to or included in a product that is produced for or placed in interstate or foreign commerce, to the economic benefit of anyone other than the owner thereof, and intending or knowing that the offense will, injure any owner of that trade secret, knowingly-

(1) steals ... such information;

(2) without authorization copies ... such information;

(3) receives, buys, or posses such information .... ${ }^{159}$

The primary difference between the mens rea elements under each statute is that under $\$ 1831$, the mens rea element is singular, and under $\$ 1832$ there is a dual mens rea requirement. Under $\$ 1831$, the only mens rea element that must be proved is that the actor acted "intending or knowing that the offense will benefit any foreign government...." ${ }^{160}$ In $\$ 1832$, the actor must act "with [1] intent to convert a trade secret ... to the economic benefit of anyone other that the owner thereof, and [2] intending or knowing that the offense will, injure any owner of that trade secret...." ${ }^{161}$ Also, the mens rea modifier "knowingly" is the last word used

157. Id.

158. Id. $\$ 1831$ (a)(1)-(3) (emphasis added).

159. Id. $\$ 1832(\mathrm{a})(1)-(3)$ (emphasis added).

160. 18 U.S.C. $\$ 1831$ (a) (2006) (emphasis added).

161. Id. \$1832(a) (emphasis added). 
in subsection (a) of both sections 1831 and $1832 .{ }^{162}$ This word attaches the mens rea elements to the actus reus elements contained in subparts (1)-(3) under both sections 1831(a) and 1832(a). ${ }^{163}$ Under these subparts, the act criminalizes the theft, misappropriation, unauthorized copying - and most notably - the knowing receipt, purchase, or possession of the trade secret information that was either stolen, appropriated, or received without the authorization of its owner. ${ }^{164}$

8. Proving Misappropriation under the EEA: United States v. Hanjuan $J{ }^{165}$ as a Framework for Analyzing Misappropriation.

There has only been one conviction under $\$ 1831$, but there have been many under $\$ 1832$ of the EEA. ${ }^{166}$ In United States $v$. Hanjuan Jin, Jin was accused of violating both sections 1831 and 1832 of the EEA. ${ }^{167}$ At her trial, Jin was found not guilty of violating the economic espionage provision found in $\$ 1831$ (a)(3), but she was convicted for the theft of trade secrets provision under $\$ 1832(\mathrm{a})(3) .{ }^{168}$ The court provided a detailed analysis that sets forth an excellent framework for proving misappropriation under the EEA.

The defendant, Jin, was an employee of Motorola, Inc. and worked and resided in Illinois. ${ }^{169}$ She worked for Motorola for seven years before taking a yearlong sabbatical, during which time she obtained concurrent employment with Sun Kaisens, a technology company that, inter alia, developed communications equipment for the Chinese military. ${ }^{170}$ After her sabbatical, Jin returned to work for Motorola for two days before resigning. ${ }^{171}$ During these two days, Jin downloaded over 5,000 of Motorola's confidential proprietary files onto an external hard disk and filled two large shopping bags with Motorola documents containing

162. Id. $\$ \$ 1831(\mathrm{a}), 1832(\mathrm{a})$.

163. Id.

164. Id. $\$ \$ 1831(\mathrm{a})(1)-(3), 1832(\mathrm{a})(1)-(3)$.

165. United States v. Hanjuan Jin, 833 F. Supp. 2 d 977 (N.D. Ill. 2012).

166. See United States v. Chung, 659 F.3d 815 (9th Cir. 2011) (convicting defendant under the economic espionage provision of the EEA).

167. Jin, 833 F. Supp. $2 d$ at 1015.

168. Id. at 1018.

169. Id. at $980-81$.

170. Id.

171. Id. at $983-85$. 
confidential information. ${ }^{172}$ The information she obtained from the computer files and physical documents related to three of Motorola's research and development projects for its iDen cellular technology. ${ }^{173}$ Jin then resigned from her job, emptied her bank accounts, and prepared to fly to China via O'Hare International Airport in Chicago. ${ }^{174}$ While passing through customs, Jin raised the suspicion of the gate agent because she falsely reported the amount of currency she was carrying into China; she also could not sufficiently explain why she was in possession of all of the Motorola equipment and files that were visibly labeled as "confidential and proprietary information." 175 The agents also discovered a military technology manual for Sun Kaisens. ${ }^{176}$ This manual indicated that Sun Kaisens was a provider of communications technology for the Chinese military. ${ }^{177}$ Jin was later placed under arrest and tried under the economic espionage and theft of trade secret provisions of the EEA. ${ }^{178}$

a. Element one: Does the information constitute a trade secret?

To be convicted under the EEA, a defendant must misappropriate information that meets the requirements necessary to constitute a trade secret. ${ }^{179}$ Under the EEA, information constitutes a trade secret if (1) the information is not known or readily ascertainable by the general public, (2) the owner of the information took reasonable measures to ensure its secrecy, and (3) the information derives economic value based upon its secrecy. ${ }^{180}$

(1) Was the information known or readily ascertainable by the public?

The Jin court found that both the electronic files and the physical documents containing the secret information did effectively constitute a

172. Id. at $984-85$.

173. Id. at 986 .

174. Id. at 986-87.

175. Id.

176. Id. at 988 .

177. Id.

178. Id. at 980 .

179. See infra Part II.A.6 (defining all of the essential definitional components of a trade secret under the EEA).

180. 18 U.S.C. $\$ 1839(3)(2006)$. 
trade secret. ${ }^{181}$ This information met the definitional elements of a trade secret because the information was "not known or readily ascertainable to the public." 182 Under EEA jurisprudence, the circuits are split as to what constitutes the term "public." 183 The Third Circuit contends that the term "public" in sections 1831 and 1832 is implicitly preceded by the word "general," meaning that the secret must not be known by the "general public" at large. ${ }^{184}$ The competing view, which is held by the Seventh Circuit, contends that the term "public" is implicitly preceded by the word "educated" or "economically important." ${ }^{185}$ Under this interpretation, the group of people embodied by the term "public" only includes those who are familiar with and engaged in the business within the pertinent field. ${ }^{186}$ In Iin, the court held that the information in question met the "not generally known by the public" requirement because the information was not known by either interpretation of "public." 187

(2) Did the business entity take reasonable measures to keep the information secret?

Second, courts will look to whether the trade secret owner took reasonable measures to keep the information secret. ${ }^{188}$ In Jin, the court found that Motorola did take reasonable measures to keep its proprietary information confidential. ${ }^{189}$ When determining whether an owner of a trade secret took reasonable security measures to ensure protection of his trade secrets, courts balance the costs of a given precautionary measure with the benefits that are obtained by way of the precautionary measures. ${ }^{190}$ This analysis is fact sensitive and each result will turn on the nature of the information, the identity of the misappropriator, and the protective measures that are employed. ${ }^{191}$ In Jin, Motorola's precautionary measures included, inter alia, monitoring the computer network for download

181. Jin, 833 F. Supp. $2 \mathrm{~d}$ at 1011.

182. Id. at 1007 (quoting the EEA, $\$ 1839(3)$ ).

183. Id.

184. United States v. Hsu, 155 F.3d 189, 196 (3d Cir. 1998).

185. United States v. Lange, 312 F.3d 263, 266-67 (7th Cir. 2002).

186. Id.

187. Jin, 833 F. Supp. 2d at 1007.

188. See supra Part II.A.6.b.

189. Jin, 833 F. Supp. $2 \mathrm{~d}$ at 1009.

190. See Rockwell Graphic Sys. v. DEV Indus., 925 F.2d 174, 179 (7th Cir. 1991).

191. Id. 
anomalies; monitoring network alarms; installing network firewalls, physical security cameras, individual access cards, and passcodes; implementing detailed security initiatives for the proper handling of classified materials; training regarding the confidentiality required of employees; and also training regarding mandatory adherence to the terms of signed confidentiality agreements. ${ }^{192}$ The confidentiality agreements detailed all specific classification levels and their concomitant requirements for handling Motorola's classified information. ${ }^{193}$ Under the EEA, while a company does not need to take "every conceivable step to protect the property from misappropriation, ${ }^{, 94}$ the Jin court described Motorola's "multi-pronged approach" as a reasonable means of maintaining the secrecy of Motorola's trade secrets. ${ }^{195}$

(3) Does the information derive independent economic value from its secrecy?

Third, courts will analyze alleged trade secret information to ascertain whether the information derives any economic value as a result of its secrecy. ${ }^{196}$ In Jin, the court held that the information that was removed from Motorola derived independent economic value from the fact that it was unknown to others. ${ }^{197}$ In United States $v$. Chung ${ }^{198}$-representing one of the first convictions under 18 U.S.C. $\$ 1831$ - the Ninth Circuit developed this element by analyzing "the degree to which the secret information confers a competitive advantage on its owner." ${ }^{\text {"199 }}$ Jin made the argument that, due to the fact that she had the personal knowledge of all of the information that she was removing from the United States, she did not face liability under the EEA. ${ }^{200}$ In essence, she asserted that she did not even need the

192. Jin, 833 F. Supp. $2 \mathrm{~d}$ at $1008-09$.

193. Id. at 1009.

194. Congressional Report, supra note 107 , at 7.

195. Jin, 833 F. Supp. $2 d$ at $1008-09$.

196. See supra Part II.A.6.c (explaining the economic value requirement of a trade secret under the EEA).

197. Jin, 833 F. Supp. $2 \mathrm{~d}$ at 1010.

198. United States v. Chung, 659 F.3d 815, 826-27 (9th Cir. 2011).

199. Id. The court stated that "[a] reasonable inference is that the information could assist a competitor in understanding how [the trade secret owner] approaches problemsolving and in figuring out how best to bid on a similar project in the future." Id. at 827 .

200. Jin, 833 F. Supp. $2 \mathrm{~d}$ at 1010. 
information because the information was already in her mind. ${ }^{201} \mathrm{Her}$ argument had some merit, as Congress noted in the Congressional Report, because the EEA does not apply to "individuals who seek to capitalize on the personal knowledge, skill, or abilities they may have developed" from their previous employment. ${ }^{202}$ The court emphasized that Jin's argument failed because she physically removed confidential information about Motorola's products and processes from the Motorola property. ${ }^{203}$ The fact that she physically removed thousands of computer files from the property served as direct evidence that Jin needed the information contained in the Motorola property; thus, Jin did not have the personal knowledge she claimed to have. ${ }^{204}$ The court held that because the information in Jin's possession could be of potential economic value to the recipient, that information derived an economic benefit from being kept secret. ${ }^{205}$

b. Element two: Did the accused possess the knowledge that the information was a trade secret?

Under both sections 1831(a)(3) and 1832(a)(3), the government must prove that the defendant knowingly "receives, buys, or possesses a [trade secret], knowing the same to have been stolen or appropriated, obtained, or converted without authorization." 206 The Jin court found that Jin satisfied the mens rea element of having the requisite knowledge that she possessed trade secrets at the time she misappropriated them. ${ }^{207}$ When looking to the statutory language of sections $1831(a)(1)-(3)$ and $1832(a)(1)-(3)$, the word "knowingly" - the last word in section (a) - modifies not only the transitive verbs at the beginning of subparts (1)-(3), but "knowingly" also modifies the object of the transitive verbs. ${ }^{208}$ Thus, the government has the burden of

201. Id.

202. Congressional Report, supra note 107 , at 7.

203. Jin, 833 F. Supp. $2 d$ at 1010-11.

204. Id.

205. Id. at 1010.

206. 18 U.S.C. $1831(a)$ and $1832(a)(3)$ replace the words "trade secret" with "such information." See 18 U.S.C. $\$ \$ 1831$ (a)(3), 1832(a)(3) (2006).

207. Jin, 833 F. Supp. $2 \mathrm{~d}$ at 1015.

208. See id. at 1012; see also Flores-Figueroa v. United States, 556 U.S. 646 (2009). When looking at a statute that was constructed similarly to 18 U.S.C. $\$ 1831(\mathrm{a})(1)-(3)$ and 1832(a)(1)-(3), the Supreme Court definitively held that the mens rea "knowingly" requirement extends to both the transitive verbs and their objects in a statute. $I d$. at 650 . The Court stated 
not only proving (as evidenced by the transitive verb) that the defendant completed the bad act, but also that the defendant knew that the information was a trade secret. ${ }^{209}$ For example, in $\$ 1832(\mathrm{a})(1)$, it must not only be proved that the defendant knowingly converted information but it also must be proved that the defendant knowingly converted information while having actual knowledge of the fact that it was a trade secret. ${ }^{210}$

The next question, then, is whether a defendant must have the knowledge that the information is a trade secret to the extent of the statutory definition stated in 18 U.S.C. $\$ 1839$ (3), or if it is enough for the government to prove that the defendant merely knew that he possessed confidential "proprietary information." 211 Currently, the circuits are split in making this determination. In United States v. Krumrei, ${ }^{212}$ the Sixth Circuit concluded that it is not necessary to prove that a defendant had actual knowledge of the fact that the stolen information was a trade secret under 18 U.S.C. $\$ 1839(3){ }^{213}$ To make this determination, the Krumrei court queried the extent of the defendant's knowledge-not of the secret information-but of the protective measures that were put in place by the trade secret owner. ${ }^{214}$ With this in mind, the court reasoned that it is not necessary for the accused to have had knowledge of the specific security measures that were employed to protect the stolen confidential information. ${ }^{215}$ The Krumrei court held that the defendant only had to know that the information was "proprietary." 16 In United States $v$. Roberts, ${ }^{217}$ the District Court for the Eastern District of Tennessee defined

[a]s a matter of ordinary English grammar, it seems natural to read the statute's word "knowingly" as applying to all the subsequently listed elements of the crime .... Where a transitive verb has an object, listeners in most contexts assume that an adverb (such as knowingly) that modifies the transitive verb tells the listener how the subject performed the entire action, including the object.

Id. (emphasis added).

209. Jin, 833 F. Supp. $2 d$ at 1012.

210. See id. at 1013-14.

211. See id. at 1012-13.

212. United States v. Krumrei, 258 F.3d 535 (6th Cir. 2001).

213. See id. at 539.

214. Id.

215. Id.

216. Id.

217. United States v. Roberts, No. 3:08-CR-175, 2009 WL 5449224, at *5 (E.D. Tenn. Nov. 7, 2009). 
"proprietary" as "belonging to someone else who has an exclusive right to it, but does not have to know that it meets the statutory definition of a trade secret." 218

On the other side of the split, in United States v. Nosal, ${ }^{219}$ the District Court for the Northern District of California required the prosecution to prove more than that the information was merely proprietary. ${ }^{220}$ In Nosal, the court required it to be proved that the defendant possessed the knowledge that the information did indeed constitute a "trade secret" according to the definitional elements of 18 U.S.C. $\$ 1839(3){ }^{221}$ This knowledge was required at the time the accused committed the appropriation. ${ }^{222}$ The court stated that the government must prove that the defendant knew the information in question possessed more than the "general" attributes of a trade secret to violate $\$ 1831$ or $\$ 1832 .{ }^{223}$

In dismissing the circuit split, the Jin court contended that this split is fictitious. ${ }^{224}$ The court reasoned that both sides arrive at the same conclusion following either path of the circuit split. ${ }^{225}$ When making this determination, the Jin court noted that if a defendant possessed actual knowledge of the information's "proprietary" nature, this knowledge establishes that he "had the general attributes of a trade secret in order to establish a violation ... of the EEA."226

c. Element three: Proving the unique mens rea requirements under Sections 1831(a) and 1832(a).

The next steps that must be taken when prosecuting an individual or corporation under the EEA is to prove the mens rea elements that are unique to either section 1831(a) or 1832(a). To be convicted under the economic espionage component of the EEA- $\$ 1831$ - the accused must intend or know that the theft of the trade secrets will benefit any foreign

218. Id. at $* 5$.

219. United States v. Nosal, No. CR 08-00237, 2009 WL 981336 (N.D. Cal. Apr. 13, 2011), rev'd, 642 F.3d 781 (9th Cir. 2011), reh'g en banc granted, 661 F.3d 1180 (9th Cir. 2011), affd, 676 F.3d 854 (9th Cir. 2012).

220. Nosal, 2009 WL 981336 , at *3.

221. Id.

222. Id.

223. Id.

224. See United States v. Hanjuan Jin, 833 F. Supp. 2d 977, 1012-13 (N.D. Ill. 2012).

225. See id. at 1011-13.

226. Id. at 1013-14. 
government. ${ }^{227}$ Under the theft of trade secrets provision of the EEA$\$ 1832$ - the prosecution must prove that the accused possessed (1) an intent to convert the trade secret information to the benefit of anyone other than the owner, and (2) that the accused possessed an intent to or knowledge that the misappropriation will injure any owner of the trade secret. ${ }^{228}$

\section{(1) Economic espionage under Section 1831: Intent to benefit any foreign government.}

Under $\$ 1831$ (a), the government must prove two interrelated parts of this element. The first element is self-explanatory-the government must prove that the intended beneficiary is a "foreign government." 229 Second, the government must prove that the accused had knowledge that his conduct would benefit the foreign government to which the information was given. ${ }^{230}$ While $\$ 1832$ limits the term "benefit" to only economic benefits, "'benefit' [as used in section 1831] is intended to be interpreted broadly." ${ }^{231}$ Here, under $₫ 1831$, it is sufficient if the accused disseminated the trade secret information to the benefit of a foreign government "in any way," not merely to the economic benefit of a foreign government. ${ }^{232}$

In Jin, the court concluded that Jin did not violate $\$ 1831$ because the link between her actions and the concomitant benefit to the Chinese government was far too attenuated. ${ }^{233}$ The court based its conclusion on the prosecution's failure to adequately prove that the Chinese government would find the technological information beneficial. ${ }^{234}$ The court pointed out that the same evidence the government relied upon to show that Jin developed technology for the Chinese military also contained information showing that the Chinese already possessed technology far superior than that which Jin misappropriated. ${ }^{235}$ Thus, because the prosecution failed to show why the Chinese government would want to use technology that is

227. See 18 U.S.C. $\$ 1831$ (a) (2006).

228. Id. $\$ 1832(\mathrm{a})$.

229. Id. $\$ 1831(\mathrm{a})$.

230. Id.

231. Congressional Report, supra note 107, at 11.

232. Id. Congress stated that "in this circumstance, benefit means not only an economic benefit but also reputational, strategic, or tactical benefit." Id.

233. United States v. Hanjuan Jin, 833 F. Supp. 2d 977, 1019-20 (N.D. Ill. 2012).

234. Id. at 1020 .

235. Id. 
inferior to what it was currently using, the prosecution failed to prove beyond a reasonable doubt that Jin violated $\$ 1831 .^{236}$

(2) Theft of trade secrets under $\$ 1832$ : Intent to benefit the recipient, and intent to injure the owner of the trade secret.

Under $\$ 1832$, the mere possession of trade secrets is not a crime. ${ }^{237}$ To establish a criminal offense under $\$ 1832$, the prosecution must first prove that the accused possessed trade secrets with the intent to misappropriate them for a personal benefit, or to the benefit of a third party. ${ }^{238}$ Under this element, defendants often raise the argument that this portion of the statute focuses on the question of whether the trade secret was, or potentially could be, of value to its recipient. ${ }^{239}$ If the information is of no value to its recipient, the accused did not violate this element. ${ }^{240}$ As a result, the primary inquiry of the statute is to ascertain the intent of the accused at the time the offense was committed. ${ }^{241}$ Thus, the only time a court will inquire into whether the trade secrets contained actual value in the mind of the end user is when that end user is the rogue employee who converted the trade secrets. ${ }^{242}$

With regard to personal benefit, the Jin court held that, at a minimum, the trade secret information that a person uses to obtain and prepare for future employment is a sufficient benefit under $\$ 1832(a) .{ }^{243}$ The court noted that there was no need for the prosecution to prove that Sun Kaisens (the intended recipient of Jin's information) had requested the information because the key focus is on the intent of the accused at the time that the trade secrets were taken. ${ }^{244}$ When looking at Jin's intent at the time that she removed the trade secrets, her intent was to either give the information to

236. Id.

237. IP Handbook, supra note 20, at 289.

238. See United States v. Hsu, 155 F.3d 189, 195 (3d Cir. 1998); see also 18 U.S.C. $\$ 1832$ (a) (2006).

239. $H s u, 155 \mathrm{~F} .3 \mathrm{~d}$ at 196 . The $H s u$ court stated that "prosecutions under $\$ 1832$ uniquely require that the defendant intend to confer an economic benefit on the defendant or another person or entity." Id.

240. See id.

241. Jin, 833 F. Supp. 2d at 1016; Hsu, 155 F.3d at 196.

242. Jin, 833 F. Supp. $2 d$ at 1016.

243. Id.

244. Id. at 1017. 
Sun Kaisens or to use the information to prepare for new employment. ${ }^{245}$ The fact that the trade secrets that Jin possessed were of little utility to Sun Kaisens was irrelevant to the court because Jin's intent at the time of their conversion was to use them for her own personal benefit of obtaining further employment, for the benefit of Sun Kaisens, or for both. ${ }^{246}$

Second, a defendant found guilty under $\$ 1832$ must have intended or known that his conduct would harm the owner of the trade secret. ${ }^{247}$ Congress stated that this requires that the accused "knew or was aware to a practical certainty" that the conduct of converting the trade secrets would cause injury to the owner of the trade secrets. ${ }^{248}$ In United States $v$. Aleynikov, ${ }^{249}$ the District Court for the Southern District of New York held that the use of trade secret information to directly compete against the true owner of the information is sufficient to establish that the defendant used the information with the intent to injure the owner. ${ }^{250}$

The confidential character and nature of the business is another factor that courts look to under the intent to injure requirement. ${ }^{251}$ Under this rationale, it is not necessary for stolen information to make it into the hands of a competitor. ${ }^{252}$ In Aleynikov, the court relied heavily on the fact that the trade secret owner, Goldman Sachs, thrived on the secretive nature of its high frequency trading business. ${ }^{253}$ In other words, because the core of the business was founded upon confidentiality and secrecy, the disclosure of that information is presumed to cause injury. ${ }^{254}$ To prove this element, the government does not need to show that there is a willing market for the purchase or use of the misappropriated information, but the government must show that the defendant knew that the owner desired to keep it secure and that the defendant at least intended to make the stolen information available for use. ${ }^{255}$ Also, when a company's trade secrets are breached, the

245. Id.

246. Id.

247. 18 U.S.C. $\$ 1832(\mathrm{a})$ (2006).

248. Jin, 833 F. Supp. 2 d at 1018.

249. United States v. Aleynikov, 785 F. Supp. 2d 46, 59 (S.D.N.Y. 2011).

250. Id. at 59 .

251. Id.

252. Jin, 833 F. Supp. $2 d$ at 1018.

253. Aleynikov, 785 F. Supp. $2 d$ at 59.

254. Id.

255. Id. 
money, time, and resources that a company expends on damage control is sufficient evidence to prove the intent to injure the owner. ${ }^{256}$

\section{d. Actus reus requirements under Sections 1831 and 1832 of the EEA}

The determination that a defendant violated one of the prohibited acts in sections $1831(a)(1)-(3)$ or $1832(a)(1)-(3)$ is not nearly as difficult to prove as the scienter elements because the EEA plainly describes the actus reus requirements under each section. ${ }^{257}$ In Jin, Jin's actions satisfied the actus reus elements of sections $1831(\mathrm{a})(3)$ and $1832(\mathrm{a})(3) .^{258}$ The facts that she downloaded thousands of documents that were outside of the scope of her Motorola responsibilities, that she continued to download files after her resignation, that she lied to the FBI agents at O'Hare International Airport, and the plethora of other incriminating evidence all were used as evidence to prove that Jin knowingly violated the actus reus elements of $\$ 1832.259$

9. State Survey of Civil Liability for Trade Secret Misappropriation

Even though copyrights, trademarks, and patents are uniformly enforced under federal law, trade secret law is subject to the laws of fifty-one different jurisdictions. Within the fifty states and the District of Columbia, each state's laws are either (1) partially based on the Uniform Trade Secrets Act, (2) completely based on the Uniform Trade Secrets Act, or (3) are based upon the common law approach evidenced by the Restatement of Unfair Competition. ${ }^{260}$ As evidenced by the name of the committee-the National Conference of Commissioners on Uniform State Laws-the drafters of the UTSA intended to establish uniform state laws for the protection of trade secrets. ${ }^{261}$ Despite the intent of the UTSA, each state's trade secret laws differ widely. Currently, thirty-seven states ${ }^{262}$ use differing versions of the

256. See Jin, 833 F. Supp. $2 \mathrm{~d}$ at 1018.

257. 18 U.S.C. $\$ 1831(\mathrm{a})(1)-(3), 1832(\mathrm{a})(1)-(3)(2006)$.

258. Jin, 833 F. Supp. $2 \mathrm{~d}$ at 1015.

259. Id.

260. See Uniform Trade Secrets Act with 1985 amendments $1-12$ (1985); RESTATEMENT (THIRD) OF UNFAIR COMPETITION $\$ 39-45$ (1995).

261. See Uniform Trade Secrets Act With 1985 Amendments: Prefatory Note (1985).

262. Currently, the following 37 states use a modified version of the UTSA (note: each statute cited is the first substantive statute in the series of each state's trade secret laws): Alabama (Ala. CODE $\$ 8-27-2$ (1987)); Alaska (AlaSKa STAT. $\$ 45.50 .940$ (1988)); Arizona (ARIZ. ReV. STAT. ANN. \$44-401 (1990)); Arkansas (ARK. CODE ANN. \$4-75-601 (1981)); California (CAL. CJV. Code $\$ 3426$ (West 1984)); Colorado (Colo. REv. STAT. $\$ 7-74-101$ 
UTSA for their trade secret laws. Nine states and the District of Columbia ${ }^{263}$ use the UTSA in its entirety. The remaining five states strictly adhere to the Restatement approach. ${ }^{264}$

\section{Remedies for Trade Secret Misappropriation}

a. Equitable remedies

The most common remedies for misappropriation of trade secrets are equitable remedies. ${ }^{265}$ In trade secret litigation, the equitable remedies of injunctions, royalty order injunctions, mandatory injunctions, and protective orders are the most common remedies provided. ${ }^{266}$ Both the UTSA and the Restatement of Unfair Competition recommend equitable

(1986)); Connecticut (CONN. Gen. STAT. \$ 35-50 (1983)); Georgia (GA. CODE ANN. \$10-1-760 (1990)); Hawaii (HAw. Rev. STAT. $\$ 482 \mathrm{~B}-2$ (1989)); Idaho (Idaho Code ANN. $\$ 48-801$ (1990)); Illinois (765 IlL. CoMp. STAT. 1065/2 (1988)); Indiana (IND. CODE $\$ 24-2-3-1$ (1982)); Iowa (IOWA CODE $\$ 550.1(1990)$ ); Kentucky (Ky. Rev. STAT. ANN. $\$ 365.880$ (West 1990)); Louisiana (LA. Rev. StAT ANN. \$51:1431 (1981)); Maine (ME. Rev. STAT. tit. 10, \$ 1542 (1987)); Maryland (MD. CODE ANN. COM. LAW $\$ 11-1201$ (West 2010)); Michigan (MICH. COMP. LAWS $\$ 445.1902$ (1998)); Minnesota (MINN. STaT. $\$$ 325C.01 (1986)); Mississippi (Miss. Code ANn. $\$ 75-26-3(1990)$ ); Missouri (Mo. Rev. STAT. $\$ 417.453$ (1995)); Montana (MONT. CODE ANN. \$30-14-402 (1985)); Nebraska (Neb. Rev. STAt. \$87-501 (1988)); Nevada (Nev. Rev. Stat. $\$$ 600A.010 (1987)); New Mexico (N.M. Stat. ANN. \$57-3A-1 (1989)); North Dakota (N.D. Cent. Code \$47-25.1-01 (1993)); Ohio (Ohio Rev. Code AnN. $\$ 1333.61$ (West 1994)); Oregon (OR. Rev. STAT. $\$ 646.461$ (1987)); Pennsylvania (12 PA. Cons. STAT. ANN. $\$ 5301$ (West 2004)); South Carolina (S.C. Code ANN. \$39-8-20.(1997)); South Dakota (S.D. Codified LAws $\$ 37-29-1$ (1994)); Tennessee (TENN. CodE ANN. \$47-251701 (2000)); Vermont (VT. STAT. ANN. tit. 9, \$ 4601 (1995)); Virginia (VA. CODE ANN. $\$ 59.1$-336 (2009)); Washington (WASH. REV. CODE $\$ 19.108 .010$ (1981)); Wisconsin (WIS. STAT. $\$ 134.90$ (2011)); and Wyoming (WYo. STAT. ANN. \$40-24-101 (2006)).

263. Currently, the following nine states and the District of Columbia base their trade secret laws entirely on the UTSA (note: each statute cited is the first substantive statute in the series of each state's trade secret laws): Delaware (DEL. CODE ANN. tit. 6, $\$ 2001$ (2002)); District of Columbia (D.C. CodE $\$ 36-401((1989))$; Florida (FLA. STAT. $\$ 688.001$ (1988)); Kansas (KAN. STAT. ANN. $\$ 60-3320(1981)$ ); New Hampshire (N.H. Rev. Stat. ANN. $\$ 350-$ B:1 (2011)); Oklahoma (OKLA. STAT. tit 78, $\$ 86$ (1986)); Rhode Island (R.I. GEN. LAWS $₫ 6$ 41-1 (1986)); Utah (UTAH CODE ANN. $\$ 13-24-1$ (West 1989)); and West Virginia (W. VA. CODE $\$ 47-22-1(1986))$.

264. Currently, the following five states base their trade secret laws on the common law Restatement approach: Massachusetts, New Jersey, New York, North Carolina, and Texas. See ResTATEMENT (THIRD) OF UNFAIR COMPETITION $\$ \$ 39-45$ (1995).

265. See IP Handbook, supra note 20, at 307.

266. See id. at $307,310-12$. 
remedies as the primary means of redress when a court finds that trade secrets have been misappropriated. ${ }^{267}$

b. Economic damages

When choosing between damage calculation options, "the proper measure of damages in a trade secret misappropriation case . . . has been that which affords the plaintiff the greatest recovery."268 As a result, there are six common methods of damage calculations that courts commonly use to determine appropriate damage measures when equitable remedies are inappropriate. ${ }^{269}$

\section{(1) Actual value measure}

The first measure concerns the actual value of the trade secret. ${ }^{270}$ Under this consideration, either the actual value or the diminution in value ${ }^{271}$ of the trade secret may be considered in the damage calculations. ${ }^{272}$ Courts approach this calculation by analyzing the costs that a company may incur "in acquiring the same information or trade secret through its own experimentation or through other lawful means." 273 In the event that a competitor destroys the trade secret, the actual value price calculation will be equal to the value of the trade secret to the plaintiff at the time that the trade secret was destroyed. ${ }^{274}$ If the trade secret is not destroyed, the courts

267. See Uniform TRADE SeCRETS ACT With 1985 AMENDMENTS $\$ 2$ (1985); ReSTATEMENT (THIRD) OF UNFAIR COMPETITION $\$ 44$ (1995).

268. Michael Rosenhouse, Annotation, Proper Measure \& Elements of Damages for Misappropriation of Trade Secret, 11 A.L.R. 4th 21 (1982).

269. Robin C. Sickles \& Ashok Ayyar, Evaluation of Damages Claims in a Trade Secrets Case, in EConomic Damages in INTEllectual Property: A HaNDS-ON Guide to Litigation 265, 267 (Daniel Slottje ed., 2006).

270. Id. at 267 .

271. The diminution in value method is "a way of calculating damages for breach of contract based on a reduction in market value ...." BLACK'S LAW DiCTIONARY 524 (9th ed. 2009).

272. Id.

273. See, e.g., McRoberts Software, Inc. v. Media 100, Inc., 329 F.3d 557, 570 (7th Cir. 2003).

274. Trade secrets are destroyed when a competitor misappropriates the trade secret in such a way that it is impossible for it to remain unique and secretive to its original owner. See Medtronic Vascular, Inc. v. Advanced Cardiovascular Sys., Inc., Civ.98-80-SLR, 2005 WL 388592, at ${ }^{*} 1$ n.4 (D. Del. Feb. 2, 2005). 
calculate the damages according to the diminution in value of the trade secret. ${ }^{275}$

\section{(2) Lost profits measure}

Second, courts will also evaluate the amount of profits lost by a plaintiff as a result of misappropriation. ${ }^{276}$ Lost profits are calculated by subtracting the production costs from the loss of revenues due to loss of sales. ${ }^{277}$ Courts may also make additions or deductions to the lost profit value by analysis of market conditions, inflation, or other economic factors that may influence the lost profit value. ${ }^{278}$

\section{(3) Unjust enrichment measure}

Courts also may use an unjust enrichment analysis as the third measure to calculate damages for trade secret misappropriation. ${ }^{279}$ Courts calculate unjust enrichment by considering the value of the trade secret at the time that it was misappropriated and also considering (1) the amount the plaintiff may receive by the disgorgement of the profits, ${ }^{280}(2)$ the amount of any profits derived from the collateral sales connected to the bad act, and (3) the amount of research and development costs that the defendant avoided. ${ }^{281}$ Unjust enrichment is calculated by analyzing the benefit to the defendant in relation to the extent he was able to exploit and derive economic value by use of the trade secret. ${ }^{282}$

\section{(4) Price erosion with causality measure}

Fourth, courts will look to "price erosion with causality" to measure damages. ${ }^{283}$ Under this analysis, courts will calculate the value by noting the

275. See Reading Radio, Inc. v. Fink, 833 A.2d 199, 207 (Pa. Super. Ct. 2003) (stating that "the diminution valuation requires that an appraiser value the same [property] at two points in time, i.e., a 'before and after' analysis").

276. Sickles \& Ayyar, supra note 269, at 267.

277. Pioneer Hi-Bred Int'l v. Holden Found. Seeds, Inc., 35 F.3d 1226, 1244 n.52 (8th Cir. 1994).

278. Id.

279. Sickles \& Ayyar, supra note 269, at 267.

280. Disgorgement of profits is " $t]$ he act of giving up something (such as profits illegally obtained) on demand or by legal compulsion." BLACK's LAW DiCTIONARY 536 (9th ed. 2011).

281. Sickles \& Ayyar, supra note 269, at 267.

282. Id.

283. Id. 
plaintiffs loss of profits due to a reduction in sales. ${ }^{284}$ For this valuation to be allowed, there must be an identifiable element of causation between the defendant's misappropriation and the erosion in the market price of the trade secret. ${ }^{285}$ Thus, the misappropriation must have caused the plaintiff to reduce his sales price to compete with the defendant who misappropriated his trade secret. ${ }^{286}$

\section{(5) Licensing royalty measure}

Fifth, the courts will sometimes impose a licensing royalty on all of the defendant's sales connected with the misappropriation. ${ }^{287}$ When applying this standard for damage calculations, courts often utilize the application of all or some of the fifteen factors for calculating reasonable royalties provided in the patent case Georgia Pacific v. U.S. Plywood Corp. ${ }^{288}$ "A reasonable royalty award attempts to measure a hypothetically agreed value of what the defendant wrongfully obtained from the plaintiff." 289 To calculate this hypothetical amount, courts use expert testimony and assume that there was a "suppositious meeting" between the parties, and the expert attempts to calculate an amount that he believes that the parties would have agreed upon. ${ }^{290}$ The final figure is based upon what the expert deems would have been a fair licensing price at the time that the misappropriation occurred. $^{291}$

(6) Punitive damages measure

The sixth measure of economic trade secret damages is punitive damages. The UTSA expressly provides for punitive damages in the event that the misappropriation is "willful and malicious." ${ }^{\text {"292 }}$ The UTSA, however, does cap the amount of punitive damages by stating that the damages may

284. Salisbury Labs., Inc. v. Merieux Labs., Inc., 735 F. Supp. 1555, 1579-80 (M.D. Ga. 1989).

285. Sickles \& Ayyar, supra note 269, at 267.

286. Salisbury Labs., Inc., 735 F. Supp. at 1579-80.

287. Sickles \& Ayyar, supra note 269, at 267.

288. See Georgia-Pac. Corp. v. U.S. Plywood Corp., 318 F. Supp. 1116, 1120 (S.D.N.Y. 1970).

289. Vt. Microsystems, Inc. v. Autodesk, Inc., 88 F.3d 142, 151 (2d Cir. 1996).

290. Id. (internal quotation marks omitted).

291. Id.

292. See UNIFORM TRADE SECRETS ACT WITH 1985 AMENDMENTS $\$ 3(b)$ (1985). 
not be "in an amount... exceeding twice any award [of compensatory damages]."293

\section{B. Reporter's Shield as Applied to Bloggers}

Even though the Internet is a relatively new tool for the dispersion of information, the reporter's shield has existed in some form for many years. ${ }^{294}$ One of the earliest accounts regarding the shield goes all the way back to the founding era of the United States when Benjamin Franklin's brother was imprisoned for refusing to name a confidential source. ${ }^{295}$ Despite its age, the effect of the reporter's shield remains the same-it protects a journalist from the forced disclosure of a confidential source. ${ }^{296}$

This privilege is based upon two sources of law. First, the First Amendment establishes the privilege in limited circumstances. ${ }^{297}$ Second, state specific reporter's shield laws offer a far more specific and potent form of protection when compared to the protections of the First Amendment. ${ }^{298}$ Today, courts are split on whether a blogger constitutes a traditional journalist. ${ }^{299}$ To determine whether a blogger is entitled to the traditional protections of the reporter's shield, this distinction primarily turns on the precise language of the state reporter's shield law.

293. Id.

294. Sam J. Ervin, Jr., In Pursuit of a Press Privilege, 11 HARv. J. ON LEgIs. 233, 234 (1974) (quoting Benjamin Frankin, AUTOBiography 30 (H. Weld ed., 1848)).

295. Id.

296. Harvard Law Review Ass'n, Protecting The New Media: Application of the Journalist's Privilege to Bloggers, 120 HARV. L. ReV. 996 (2007).

297. See U.S. CONST. amend. I. "Congress shall make no law respecting an establishment of religion, or prohibiting the free exercise thereof; or abridging the freedom of speech, or of the press; or the right of the people peaceably to assemble, and to petition the Government for a redress of grievances." Id. (emphasis added).

298. Id.

299. See O’Grady v. Superior Court, 44 Cal. Rptr. $3 d 72$ (Cal. Ct. App. 2006) (holding that the reporter's privilege applies to bloggers); see also Blumenthal v. Drudge, $992 \mathrm{~F}$. Supp. 44 (D.D.C 1998) (holding that the reporter's privilege may apply to an online blogger). Contra Too Much Media, LLC v. Hale, 20 A.3d 364 (N.J. 2011) (holding that the reporter's privilege may not apply to a blogger to shield him from a defamation suit). 
1. Reporter's Shield Protection under the First Amendment Protection

In the 1972 case Branzburg v. Hayes, ${ }^{300}$ the Supreme Court held that a journalist does not have an absolute right to not testify when called before a grand jury, but he has a limited right to protection under the First Amendment. ${ }^{301}$ The Branzburg Court established a three-part balancing test to determine whether a newsman possesses the right to refrain from revealing a confidential source. ${ }^{302}$ Under this test, courts are to weigh the freedom of the press against the public's interest in obtaining the information ${ }^{303}$ Reiterating the value of the journalist and his contribution to the dissemination of information to the general public, Justice Powell concluded by ensuring reporters that "the courts will be available [to provide remedies] to newsmen under circumstances where legitimate First Amendment interests require protection." ${ }^{\text {"304 }}$

\section{State Survey of Reporter's Shield Protection}

Currently, 40 states and the District of Columbia have enacted reporter's shield laws protecting journalists. ${ }^{305}$ Only ten states have no reporter's shield statutes. ${ }^{306}$

300. Branzburg v. Hayes, 408 U.S. 665 (1972).

301. Id. at 709 (Powell, J., concurring).

302. Id. at 710 .

303. Id. In Justice Stewart's dissent, he propounded a three-part test that courts should apply to determine whether the privilege applies. Id. at 743 (Stewart, J., dissenting). Justice Stewart stated that

the government must (1) show that there is probable cause to believe that the newsman has information that is clearly relevant to a specific probable violation of law; (2) demonstrate that the information sought cannot be obtained by alternative means less destructive of First Amendment rights; and (3) demonstrate a compelling and overriding interest in the information.

Id. (Stewart, J., dissenting).

304. Id. at 710 .

305. Currently, the following 40 states, and the district of Columbia, have enacted state reporter's shield statutes (note: each statute cited is the first substantive statute used in each state's trade secret laws): Alabama (ALA. CODE $\$ 12-21-142$ (2011)); Alaska (ALASKA STAT. $\$ 09.25 .300$ (2011)); Arizona (ARIz. REv. STAT. ANN. $\$ 12-2237$ (2011)); Arkansas (ARK. CODE ANN. \$16-85-510 (2011)); California (CAL. Const. art. I, \$2(b)); Colorado (Colo. Rev. STAT. $\$ 13-90-119$ (1990)); Connecticut (ConN. Gen. STAT. \$ 52-146t (2006)); Delaware (Del. CODE ANN. tit. 10, $\$ 4320$ (2002)); District of Columbia (D.C. CODE $\$ 16-4701$ (1992)); Florida (FLA. STAT. $\$ 90.5015$ (1998)); Georgia (GA. CODE ANN. \$24-9-30 (1990)); Hawaii (proposed and not yet enacted) (H.R. 2016, 26th Leg., Reg. Sess. 2012 (Haw. 2012)); Illinois (735 Ill. Comp. 
In O'Grady v. Superior Court, ${ }^{307}$ Apple, Inc. brought suit against Jason O'Grady for allegedly disseminating Apple's trade secrets on O'Grady's technology blog. ${ }^{308}$ The information source was undisclosed on the blog, and when asked to provide the information, O'Grady raised the reporter's shield privilege as a defense. ${ }^{309}$ The California shield law, which O'Grady relied upon, is illustrative of most state shield statutes and provides that

[a] publisher, editor, reporter, or other person connected with or employed upon a newspaper, magazine, or other periodical publication ... shall not be adjudged in contempt ... for refusing to disclose the source of any information procured while so connected or employed for publication in a newspaper, magazine or other periodical publication, or for refusing to disclose any unpublished information obtained or prepared in gathering, receiving or processing of information for communication to the public..$^{310}$

STAT. 5/8-901 (1991)); Indiana (IND. CODE $\$ 34-46-4-2$ (1998)); Kansas (KAN. STAT. ANN. $\$ 60-480$ (2010)); Kentucky (KY. REV. STAT. ANN. $\$ 421.100$ (West 1952)); Louisiana (LA. Rev. Stat ANn. \$ 45:1451 (2012)); Maine (ME. Rev. Stat. AnN. tit. 16, \$ 61 (2007)); Maryland (Md. Code ANN. CTs. \& JUd. Proc. \$9-112 (West 1988)); Michigan (Mich. CoMP. LAWS $₫$ 767A.6 (1995)); Minnesota (MINN. STAT. $\$ 595.023$ (1998)); Montana (MONT. CODE ANN. \$26-1-902 (2009)); Nebraska (Neb. Rev. STAT. \$20-145(1973)); Nevada (NEv. Rev. STAT. $\$ 49.275$ (1975)); New Jersey (N.J. STAT. ANN. \$2A:84A-21 (West 1977)); New Mexico (N.M. STAT. ANN. \$38-6-7 (1973)); New York (N.Y. Civ. Rights Law \$79-h (McKinney 1990)); North Carolina (N.C. GEN. STAT. \$ 8-53.11 (1999)); North Dakota (N.D. CeNT. CODE $\$$ 31-01-06.2 (1973)); Ohio (OHIO REv. CODE ANN. $\$ 2739.12$ (West 1953)); Oklahoma (OKLA. STAT. tit. 12, 2506 (1994)); Oregon (OR. REV. STAT. $\$ 44.520$ (1973)); Pennsylvania (42 Pa. Cons. STAT. ANN. $\$ 5942$ (West 1976)); Rhode Island (R.I. Gen. LaWs $\$ 9-19.1-2$ (1971)); South Carolina (S.C. CODE ANN. \$19-11-100 (1993)); Tennessee (TENN. CoDE ANN. $\$ 24-1-208$ (1973)); Texas (TeX. Civ. Prac. \& REM. Code ANN. $\$ 22.021$ (West 2009)); Utah (UTAH R. Evid. 509 (2012)); Washington (WASH. REV. CODE $\$ 5.68 .010$ (2007)); West Virginia (W. VA. CODE $\$ 57-3-10$ (2011)); and Wisconsin (WIS. STAT. $\$ 85.14$ (2012)).

306. The following 10 states have not enacted legislation to establish a state reporter's shield law: Idaho, Iowa, Massachusetts, Mississippi, Missouri, New Hampshire, South Dakota, Utah, Virginia, and Wyoming.

307. O'Grady v. Superior Court, 44 Cal. Rptr. 3d 72 (Cal. Ct. App. 2006).

308. Id. at 76. The trade secret information that was published on O'Grady's website was information pertaining to an unreleased Apple product relating to its music software. Id. at 77.

309. Id. at 81 .

310. CAL. CONST. art. I, $₫ 2(b)$ (emphasis added). 
Apple asserted that the California shield law did not protect O'Grady for three reasons: (1) O'Grady's blog was not "legitimate journalism," ${ }^{\text {"311 }}$ (2) O'Grady was not a traditional reporter and thus not a Covered Person under the shield law, ${ }^{312}$ and (3) O'Grady's blog was a not a Covered Publication under the law. ${ }^{313}$

a. Legitimate journalism requirement

Apple argued that the content of O'Grady's blog was not legitimate journalism because it was not the journalistic reporting of the news but was the verbatim posting of copies of Apple's trade secrets with no editorial oversight or changes in the material. ${ }^{314}$ Apple reminded the court that the purpose behind a state reporter's shield law is to maintain open channels for the dissemination of information to the general public, but it also argued that O'Grady's dissemination of trade secrets did not qualify for legitimate journalism because a reporter has no right to publicize trade secrets. ${ }^{315}$ Stunningly, the court stated, "We decline the implicit invitation to embroil ourselves in questions of what constitutes 'legitimate journalis[m].' The shield law is intended to protect the gathering and dissemination of news, and that is what [O'Grady] did here." 316 Despite the fact that O'Grady posted information that he knew was a closely-guarded trade secret, made no substantive changes to the information, and provided no editorial oversight, the court rationalized that his journalistic purposes were legitimate because O'Grady was engaged in the dissemination of a particular kind of information to an interested readership. ${ }^{317}$

b. Covered person requirement

Changes in technology and society have made the lines between private citizen and journalist exceedingly difficult to draw. This distinction may be simplified by the aid of the statutory language, but it may also fall to the discretion of the court as it did in O'Grady. ${ }^{318}$ The California reporter's shield statute ensures protection to a "publisher, editor, reporter, or other

311. O'Grady, 44 Cal. Rptr. 3d. at 97 (internal quotation marks omitted).

312. Id. at 99.

313. Id. at $99-100$.

314. Id. at 97.

315. Id.

316. Id. (emphasis added).

317. Id. at 98.

318. Id. at 115. 
person connected with or employed upon a newspaper, magazine, or other periodical publication." ${ }^{\prime 19}$ The O'Grady court held that O'Grady was a covered person because he posted legitimate journalism to the news site. ${ }^{320}$ The court stated that O'Grady was a "publisher" of the information because he is "[o]ne whose business is the issuing of books, newspapers, music, engravings, or the like, as the agent of the author or owner ... and ... distribution to the booksellers and other dealers, or to the public."'321 The court reasoned that the existence of an online blog is "like" a newspaper or magazine for the purposes of employing O'Grady. ${ }^{322}$

\section{c. Covered publication requirement}

All state-specific reporter's shield statutes require that the disseminated information be a "covered publication." ${ }^{323}$ The O'Grady court looked to the text of the California reporter's shield statute, which covers a "newspaper, magazine, or other periodical publication." ${ }^{324} \mathrm{~A}$ "newspaper," the court said, "has always meant, and continues to mean, a regularly appearing publication printed on large format, inexpensive paper," and did not apply to the O'Grady case. ${ }^{325}$ The court then carefully analyzed "magazine" and "other periodical publication," and concluded that O'Grady's blog could potentially fall within the scope of each of these categories. ${ }^{326}$ In relation to the magazine, the court reasoned that because there are many online

319. CAL. CONST. art. I, $\$ 2(b)$.

320. O'Grady, 44 Cal. Rptr. 3d. at 99.

321. Id. (quoting 12 OXFORD ENGLISH DICTIONARY 785 (2d ed. 1989)).

322. Id.

323. Covered publications are enumerated within the text of the state reporter's shield statute. See, e.g., News Media Privilege, MD. Code AnN. CTs. \& Jud. Proc. \$ 9-112(a) (West 1988) (enumerating "newspapers," "magazines," "press associations," "news agencies," "wire services," "radio," "television," and "any printed, photographic, mechanical, or electronic means of disseminating news and information to the public" as covered publications under the Maryland reporter shield statute).

324. O'Grady, 44 Cal. Rptr. 3d at 99-100.

325. Id. at 100 .

326. Id. The court did not conclusively state that blogs are included under "magazines" and "other publications" because the court reasoned that the there was sufficient ambiguity within the text of the reporter's shield statute. Id. Due to the ambiguity, under California law, courts "'attempt to ascertain the Legislature's purpose by taking its words in the sense in which they were understood at the time the statute was enacted." Id. (quoting Resure, Inc. v. Superior Court, 49 Cal. Rptr. 2d 354, 359 (1996)). 
magazines-that have no print counterpart-O'Grady's blog was similar and could potentially fall under its definition. ${ }^{327}$

As for the term "other periodical publication," the court employed the canon of statutory construction ejusdem generis. ${ }^{328}$ This canon is used "when a general word or phrase follows a list of specifics"; in such a case, "the general word or phrase will be interpreted to include only items of the same class as those listed." 329 The O'Grady court stated that use of ejusdem generis rests upon the premise that "if the Legislature had intended the general words to be used in their unrestricted sense, it would not have mentioned the particular things or classes of things which would in that event become mere surplusage." 330 The court reasoned that although blogs were not in existence at the time that the California shield law was drafted and enacted, through the use of ejusdem generis, the core purpose of the law is effectuated by extending the meaning of "other periodical publication" to include blogs. ${ }^{331}$

\section{PROBLEM}

Even though a corporation's trade secrets may be one if its most valuable assets, current trade secret law has made it convenient and cost effective for a company to misappropriate a trade secret that belongs to someone else. ${ }^{332}$ Generally, intellectual property values have a substantial impact on the American economy. It has been estimated, as of 2005, that intellectual property in the United States is valued anywhere from \$5-5.5 trillion. ${ }^{333}$ This estimate is roughly worth $45 \%$ of the American gross domestic product (GPD), and it is "greater than the GDP of any other nation in the world." ${ }^{334}$ The American Society for Industrial Security (ASIS) estimates that Fortune 1000 companies lost more than $\$ 49$ billion in 1999 and as much as $\$ 59$

327. Id.

328. Id.

329. BLACK'S LAW DICTIONARY 594 (9th ed. 2009). Ejusdem generis literally means "of the same kind or class." Id.

330. O'Grady, 44 Cal. Rptr. 3d. at 101.

331. Id.

332. See Ahlert v. Hasbro, Inc., 325 F. Supp. $2 d 509$ (D.N.J. 2004); see also Softel, Inc. v. Dragon Med. \& Sci. Commc'ns, Inc., 118 F.3d 955 (2d Cir. 1997).

333. Kevin A. Hasset \& Robert J. Shapiro, The Economic Value of Intellectual Property, SONECON, LLC 2 (Oct. 2005), http://www.sonecon.com/docs/studies/IntellectualPropertyReportOctober2005.pdf.

334. Id. 
billion in 2001 as a result of trade secret misappropriation. ${ }^{335}$ Collectively, for all United States corporations, ASIS estimates that trade secret theft costs corporations over $\$ 300$ billon per year in the United States. ${ }^{336}$ Under current trade secret law, a victim of misappropriation may be left with little or no legal recourse for the theft or unwarranted dissemination of his trade secrets. Consider the following three factual scenarios.

The first scenario involves parties that are in federal court under diversity jurisdiction. ${ }^{337}$ Under this scenario, Business $A$ is from one state, and Business $B$ is from a different state. Business $B$ is the defendant and is being sued for the misappropriation of a trade secret. Business $A$ is suing because one of its employees left the company, now works in a different state for Business B, and the employee revealed a confidential trade secret to his new employer, Business B. Pursuant to applicable choice of law provisions for this federal diversity action, the court applies the law of the jurisdiction of Business B. Under this state's law, the trade secret information does not qualify as a trade secret as it would under the law of the state wherein Business $A$ is incorporated. Because of this difference, the plaintiff has no case because he cannot sue for misappropriation of that which is not a trade secret.

The second scenario can arise where it is advantageous for a corporation to risk a misappropriation lawsuit to steal a competitor's trade secrets. ${ }^{338}$ Under this scenario, Business A will contact Business B and will make an offer to purchase the secret information. When Business B declines, Business A-in bad faith-calculates a way to gain control of the trade secrets. In bad faith, Business A offers an employee of Business B a generous salary on the condition that the employee provides the coveted information to Business A. Eventually, the employee leaves Business B, takes the offer to work for Business A, and divulges the trade secrets. Once Business B finds out about the misappropriation, its recourse is to file suit against Business A. Nevertheless, even though Business A may be enjoined from practicing

335. Office of the National Counterintelligence Executive, Annual Report to Congress on Foreign Economic Collection and Industrial Espionage-2002, FED'N OF AM. SCIENTISTS 1 (Feb. 2003), http://www.fas.org/irp/ops/ci/docs/2002.pdf.

336. Id. at 2.

337. This is based on the factual scenario presented in Ahlert v. Hasbro, Inc. See Ahlert v. Hasbro, Inc., 325 F. Supp. 2d 509, 511 (D.N.J. 2004).

338. This factual scenario is based upon the facts presented in E.I. du Pont de Nemours of Co. v. Kolon Indus., Inc. and Advanced Marine Enterprises, Inc. v. PRC, Inc. See E.I. du Pont de Nemours \& Co. v. Kolon Indus., Inc., 637 F.3d 435, 440 (4th Cir. 2011); Advanced Marine Enters., Inc. v. PRC, Inc., 501 S.E.2d 148, 151-52 (Va. 1998). 
the trade secret, if Business A sufficiently destroyed the trade secret by making it generally known, then the only remedy available will be monetary damages ${ }^{339}$ In many circumstances, the bad faith strategy of Business A will effectively allow for a forced purchase of Business B's trade secrets.

The third scenario, ${ }^{340}$ like the misappropriation that took place in O'Grady v. California, occurs when an employee takes a corporation's valuable trade secret, provides the information to an Internet blog, and then the blog posts the information for all of the world to see. ${ }^{341}$ Under this scenario, the likelihood is high that the trade secret is destroyed because it is no longer a secret. ${ }^{342}$ Like O'Grady, the blogger may be impervious to any liability because of his state's reporter's shield statute. ${ }^{343}$ Under this scenario, a company may destroy a competitor's trade secret and leave the victim with no possible legal redress.

All of these scenarios are possible because of the problems with current trade secret law. First, because each state has its own set of trade secret laws, the results of litigation are unpredictable and costly to plaintiffs in trade secret litigation. These results are inconsistent because of the differing application of substantive state law, the inconsistency of trade secret defenses, and the varying and inconsistent availability of state reporter's shield statutes. Second, it is increasingly difficult for trade secret plaintiffs to avail themselves of trade secret protection because of the strictness of the reasonable measure of protection doctrine. ${ }^{344}$ This burden has become increasingly onerous for corporations, requiring them to prove that a trade secret was protected adequately, and as a result plaintiffs are losing cases before they even begin. Third, the EEA is rarely used for the enforcement of trade secrets. Because economic damages may not be a substantial

339. See supra Part II.A.10.b.(1) (explaining that when a trade secret is disseminated to the extent that the trade secret owner alleges and proves that it is destroyed, the owner may only seek monetary damages).

340. This factual scenario is based upon the facts presented in O'Grady v. Superior Court. See O'Grady v. Superior Court, 44 Cal. Rptr. 3d 72, 77-83 (Cal. Ct. App. 2006).

341. See id. (holding that the reporter's privilege applies to bloggers); see also Blumenthal v. Drudge, 992 F. Supp. 44 (D.D.C. 1998) (holding that the reporter's privilege applies to an online blogger). Contra Too Much Media, LLC v. Hale, 20 A.3d 364 (N.J. 2011) (holding that the reporter's privilege does not apply to a blogger to shield him from a defamation suit).

342. See Medtronic Vascular, Inc. v. Advanced Cardiovascular Sys., Inc., Civ.98-80-SLR, 2005 WL 388592, at *1 n.4 (D. Del. Feb. 2, 2005).

343. See supra Part II.B.2 (explaining the variations of state reporter's shield statutes).

344. See supra Part II.A.6.b (explaining the reasonable measure of protection doctrine as it pertains to the definitional requirements for a trade under 18 U.S.C. $\$ 1839(3)$ )). 
deterrence to some corporations, the lack of EEA enforcement has removed the viability of trade secret misappropriation.

\section{A. Inconsistency Leads to Confusion and a Lack of Continuity.}

1. Choice of Law Conflicts Lead to Confusion and Disparate Results.

Absent a contract dictating a controlling choice of law agreement between parties, pursuant to Klaxon $v$. Stentor Electric, ${ }^{345}$ a court must apply the choice of law rules of the state where it sits. ${ }^{346}$ Illustrative of this, in Softel, Inc. v. Dragon Medical, ${ }^{347}$ the court considered which choice of law provision would apply in a trade secret case. ${ }^{348}$ The case was a diversity case with parties from New Hampshire and Delaware, but the misappropriation occurred in New York. ${ }^{349}$ Under Klaxon's rule of allowing the sitting court to apply its state's choice of law rules, the court applied "an 'interest analysis' to its choice of law, under which the law of the jurisdiction having the greatest interest in the litigation controls. ${ }^{\prime \prime 30}$ The Softel court concluded that New York substantive law would apply because the plaintiff had offices in New York, and the bad act occurred in New York. ${ }^{351}$

As evidenced by the Softel case, choice of law determinations may be crucial in determining the outcome of trade secret litigation. In one jurisdiction, information ${ }^{352}$ may qualify fully as a trade secret, whereas in the forum jurisdiction, the substantive state law may not allow the information to qualify as a trade secret. In Ahlert v. Hasbro, Inc., ${ }^{353}$ this was the result. ${ }^{354}$ The plaintiff was a toy designer from Oklahoma who travelled to New Jersey to present a design for a toy water gun pressure system to a potential buyer. ${ }^{355}$ In Oklahoma, which is one of the nine states that bases all of its trade secret law upon the UTSA, the designer's research and

345. Klaxon v. Stentor Elec. Mfg. Co., 313 U.S. 487 (1941).

346. Id. at 494 .

347. Softel, Inc. v. Dragon Med. \& Sci. Commc'ns., Inc., 118 F.3d 955 (2d Cir. 1997).

348. Id. at 967.

349. Id. at 968 .

350. Id. at 967 .

351. Id. at 968 .

352. See supra Part II.A.6.a (defining the term information within the context of trade secret law).

353. Ahlert v. Hasbro, Inc., 325 F. Supp. $2 d 509$ (D.N.J. 2004).

354. Id. at 512 .

355. Id. 
development satisfied all of the criteria to meet the UTSA definitional elements of a trade secret. ${ }^{356}$ Nevertheless, the District Court for the District of New Jersey applied a "governmental interest" test and concluded that New Jersey law applied. ${ }^{357}$ New Jersey, one of the few states that utilizes the common law restatement approach, requires that for the information to constitute a trade secret, it must be used in business. ${ }^{358}$ Since the information had not officially been used in business, the plaintiff was left without a remedy. ${ }^{359}$

2. Now You See It, Now You Don't: The Vanishing Inevitable Disclosure Doctrine.

State substantive law also governs the availability of applicable arguments that a plaintiff may assert. The Inevitable Disclosure theory protects a company by enjoining all former employees from working for a competing business where it is inevitable that the former employee will disclose the information. ${ }^{360}$ In Lam Research Corp. v. Deshmukh, ${ }^{361}$ the Ninth Circuit applied the "most significant relationship" test to determine the applicable law. ${ }^{362}$ The plaintiff's headquarters were located in California, and the defendant lived in Washington. ${ }^{363}$ The court concluded that California law applied to the case. ${ }^{364}$ This was fatal to the plaintiff's claim because he relied upon the inevitable disclosure cause of action, which is available in Washington but not in California. ${ }^{365}$ As a direct result of the variations in the states' trade secret laws, at one moment the plaintiff had full use of the

356. Id.

357. Id. Under New Jersey's "governmental interest test" for determining choice of law, a court must first identify "the policies underlying the laws of each interested jurisdiction and then consider the contacts that each jurisdiction has with the parties. The determinative law is that of the state with the greatest interest in governing the particular issues" of the case. Id.

358. Id. at 512-13.

359. Id. at 515.

360. IP Handbook, supra note 20, at 309.

361. Lam Research Corp. v. Deshmukh, 157 Fed. App'x 26 (9th Cir. 2005).

362. Id. at 27. The "most significant relationship" test considers the balancing of the following factors: the place where the injury occurred; the place where the conduct causing the injury occurred; the domicile, residence, nationality, place of incorporation, and place of business of the parties; and the place where the relationship, if any, between the parties is centered. Id. (citing ReSTATEMENT (SECOND) OF CONFLICT OF LAWS $\$ 145(2)(1971)$ ).

363. Id.

364. Id.

365. Id. at 28 . 
inevitable disclosure claim, and then at the very next moment the claim vanished, leaving the plaintiff with no cause of action. ${ }^{366}$

3. Information Laundering: Protected Trade Secret Misappropriation Under State Shield Statutes.

Perhaps the most egregious loophole in modern trade secret jurisprudence is the use of reporter shield laws to allow the safe and anonymous destruction of a trade secret-all without providing any available remedy to the trade secret owner. In $\mathrm{O}^{\prime} \mathrm{Grady},{ }^{367}$ the court shied away from regulating the bad faith dissemination of Apple's trade secretand it was all in the name of journalism. ${ }^{368}$ If, however, a trade secret was disseminated from a blog in a state like Virginia, then the plaintiff would be able to adequately identify the defendant and bring a subsequent suit because Virginia does not have a reporter's shield statute to protect a trade secret defendant.

The reporter shield statutes are highly beneficial for the law and for the American public. The problem arises when reporter's shield statutes are used to conceal bad acts, like the misappropriation of trade secrets. Texas, for instance, has ameliorated this problem by establishing two sets of shield laws-a set of civil reporter's shield laws that apply to general newsgathering and a completely separate shield law that applies only to criminal actions. ${ }^{369}$

\section{B. Many States' Trade Secret Laws Place Too Onerous of a Burden on Businesses to Prove the Existence of a Trade Secret.}

Even though the comments section of the UTSA states that "[ $t]$ he courts do not require that extreme and unduly expensive procedures be taken to protect trade secrets against flagrant industrial espionage," this perception differs markedly from the reality in trade secret litigation. ${ }^{370}$ This reality has been expressed by many courts requiring a written confidentiality agreement as a necessary predicate to the enforcement of any trade secret

366. Id.

367. See supra Part II.B.2 (explaining the impact of the O'Grady decision).

368. See O'Grady v. Superior Court, 44 Cal. Rptr. 3d 72, 98 (Cal. Ct. App. 2006).

369. Compare TeX. Civ. Prac. \& Rem. Code ANN. $\$ 22.021$ (West 2009) (Texas civil journalist's privilege), with TEX. CODE CRIM. Proc. ANN. art. 38.11 (West 2009) (Texas criminal journalist's privilege).

370. See Uniform Trade SeCrets Act with 1985 Amendments $\$ 1 \mathrm{cmt}$. at 7-8 (1985). 
protection. ${ }^{371}$ Some jurisdictions have contemplated that a confidentiality agreement is necessary for enforcing a trade secret; ${ }^{372}$ other jurisdictions have noted that an "explicit promise of confidentiality is not necessary if the recipient of the information knew or should have known that the information" was proprietary. ${ }^{373}$

Another example of this onerous burden is when courts demand too strict of an application of the company's "reasonable measures of secrecy" with regard to the trade secret. ${ }^{374}$ This occurs when courts stretch the reasonable measures of secrecy standard too far by holding that a trade secret owner did not take reasonable measures due to a mere technicality. In Motor City Bagels, Inc. v. American Bagel Co. ${ }^{375}$ the District Court for the District of Maryland held that a trade secret owner did not take reasonable measures of secrecy when he provided an "extensive confidentiality agreement" to potential investors, but the trade secret owner did not receive all of the confidentiality forms back from the investors. ${ }^{376}$ In Ruckleshaus $v$. Monsanto Co. ${ }^{377}$ the Supreme Court held that the disclosure of a trade secret "to others who are under no obligation to protect the confidentiality of the information" extinguishes the property right in the disclosure. ${ }^{378}$ Applying the Ruckleshaus rule to the facts of Motor City Bagels would and should produce a different result. In Motor City Bagels, the defendant had knowledge of the proprietary nature of the information by virtue of the confidentiality agreement he had in his possession. ${ }^{379}$ This constructive knowledge should have been enough to put the defendant on notice that the

371. See, e.g., Dicks v. Jensen, 768 A.2d 1279, 1284 (Vt. 2001) (holding that a confidentiality agreement is necessary for the enforcement of a trade secret claim regarding secret ingredients for a pizza crust recipe).

372. See, e.g., Bus. Designs, Inc. v. Midnational Graphics, LLC, No. 01-1087, 2002 WL 987971, at ${ }^{*} 6$ (Hecht, J., dissenting) (Iowa Ct. App. May 15, 2002).

373. See, e.g., Zemco Mfg., Inc. v. Navstar Int'l Transp. Corp., 759 N.E.2d 239, 247 (Ind. Ct. App. 2001). The best practice is to secure a written confidentiality agreement in all circumstances, but the written requirement should not be a prerequisite to the reasonable efforts requirement.

374. See supra Part II.A.6.b (describing the reasonable measures of secrecy standard under 18 U.S.C. $\$ 1839$ ).

375. Motor City Bagels, LLC v. Am. Bagel Co., 50 F. Supp. 2d 460 (D. Md. 1999).

376. Id. at 480 .

377. Ruckleshaus v. Monsanto Co., 467 U.S. 986 (1984).

378. Id. at 1002 .

379. Motor City Bagels, L.L.C., 50 F. Supp. $2 \mathrm{~d}$ at 480. 
information was proprietary; thus, the end result should have satisfied the reasonable measures requirement.

Additionally, different jurisdictions-even jurisdictions that follow the same substantive trade secret laws - have varying standards for determining whether an owner maintained reasonable measures of secrecy. Illustrative of the inconsistency that varies from jurisdiction to jurisdiction are lines of trade secret cases that focus on proper disposal methods for proprietary information. Some jurisdictions, as evidenced by Frank $W$. Winne \& Son, Inc. v. Palmer, ${ }^{380}$ hold that a trade secret owner has failed to maintain the reasonable efforts standard when the trade secret information is placed in a dumpster that is serviced by the local garbage collector. ${ }^{381}$ The Winne court, applying Pennsylvania law, ${ }^{382}$ relied on the Supreme Court's holding in California v. Greenwood ${ }^{383}$ and held that a trade secret owner "has no reasonable expectation of privacy from prying eyes" in the contents of his trash. ${ }^{384}$

380. Frank W. Winne \& Sons, Inc. v. Palmer, No. 91-2239, 1991 WL 155819 (E.D. Pa. Aug. 7, 1991).

381. Id. at *3. In Winne, the proprietary information in question was a listing of customers, invoices, and other business documents that qualified as trade secrets belonging to a rope manufacturing company. $I d$. at ${ }^{*} 1-2$. The documents were placed in a bag of trash that was discovered by the investigator of a competitor. $I d$. at ${ }^{*} 1$. The competitor hired an investigator to pilfer through Winne's dumpster hoping to find trade secrets. Id. The documents in question were enclosed within a bag of trash in a dumpster that was located on the immediate property. Id.

382. Pennsylvania's trade secret law in 1991, when Winne was decided, was reflective of the common law Restatement approach. In 2004, Pennsylvania changed to a partial UTSA jurisdiction. See supra Part II.A.9.

383. California v. Greenwood, 486 U.S. 35 (1988). The Greenwood Court held that refuse is left

at the curb for the express purpose of conveying it to a third party, the trash collector, who might himself have sorted through [the] trash or permitted others, such as the police, to do so. Accordingly, having deposited their garbage "in an area particularly suited for public inspection and, in a manner of speaking, public consumption, for the express purpose of having strangers take it," respondents could have had no reasonable expectation of privacy in the inculpatory items that they discarded.

Id. at 40 (citations omitted). Even though Greenwood is a Fourth Amendment criminal case, the Winne court applied its rule and held that a trade secret owner cannot maintain the secret status of his trade secret in an area where he does not have any reasonable expectation of privacy. Frank W. Winne \& Sons, Inc., 1991 WL 155819 , at ${ }^{*}$.

384. Id. 
On the opposite end of the spectrum, some jurisdictions hold that a person maintains the reasonable efforts of secrecy standard when he discards his information in the exact manner of that in Winne. In Steven Slesinger, Inc. v. Walt Disney Co. ${ }^{385}$ a court applying California law held that any information that is obtained following the Winne method of using an investigator to retrieve the information from the trash is an impermissible practice to obtain corporate information. ${ }^{386}$ The court held that this "misconduct . . . was deliberate and egregious-more than adequate to invoke the [lower] court's exercise of its inherent power ...." 387

\section{Is the EEA a Secret? The Lack of Use of the EEA}

Out of the thousands of trade secret cases that are tried every year in the United States, a disproportionate number of these cases are actually prosecuted under the EEA. In 2010, for example, the FBI opened 150 new intellectual property cases, while only 40 of those cases were related to the theft of trade secrets, and only 26 were specific to the EEA. ${ }^{388}$ This was an increase of $42 \%$ as compared to $2009,{ }^{389}$ but it was only a minimal amount of trade secret litigation in comparison to the 482 trade secret cases that were tried in federal courts during 2008. ${ }^{390}$ These statistics do not include cases that were heard in state courts, which are also eligible for EEA prosecution in most circumstances. According to these statistics, the bottom line is that only $.05 \%$ of all trade secrets cases are prosecuted under the EEA.

385. Stephen Slesinger, Inc. v. Walt Disney Co., 66 Cal. Rptr. 3d. 268 (Cal. Ct. App. 2007).

386. Id. at 293.

387. Id.

388. Press Release, Federal Bureau of Investigation, Department of Justice Joins in Launch of Administration's Strategic Plan on Intellectual Property Enforcement as Part of Ongoing IP Initiative (June 22, 2010), available at http://www.fbi.gov/news/pressrel/pressreleases/department-of-justice-joins-in-launch-of-administration2019s-strategic-plan-onintellectual-property-enforcement-as-part-of-ongoing-ip-initiative.

389. Gordon M. Snow, Statement Before the Senate Judiciary Committee in Washington, D.C., Federal BurEau of InVESTigation (June 22, 2010), http://www.fbi.gov/news/testimony/intellectual-property-law-enforcement-efforts.

390. David S. Almeling et al., A Statistical Analysis of Trade Secret Litigation in Federal Courts, 45 Gonz. L. Rev. 291, 299 (2010). 


\section{PROPOSAL}

\section{A. Trade Secret Law Should Become an Exclusively Federal Domain Like Copyrights, Trademarks, and Patents.}

Sam Dedio manages funds for the Swiss bank Julius Baer. ${ }^{391}$ These new funds have extremely limited assets, and years ago Dedio would have had to go to the trouble of finding brokers to sell the funds, and finding these brokers would drive up Dedio's costs immensely. ${ }^{392}$ Today, however, investors like Dedio do not need to find brokers to sell for them because they can use the Internet to do it themselves. With these cost savings, investors can quickly earn the ratings that they need to become high-level investors. This is all possible for Dedio and millions of other business owners because the Internet makes "even small companies global now."

Due to the impact of the Internet and modern commerce, trade secrets should fall under federal court jurisdiction like all other intellectual property. Currently, trade secrets are the only form of intellectual property that are governed by state law. Article I, section 8 , clause 8 of the United States Constitution provides that Congress has the power " $[t]$ o promote the Progress of Science and useful Arts, by securing for limited Times to Authors and Inventors the exclusive Right to their respective Writings and Discoveries." ${ }^{\text {"394 }}$ Under this clause, Congress is given the authority to establish federal patent and copyright law. Trademark protections-which are also governed by federal law-are not created by Article I, section 8 , clause 8 , but are established pursuant to the authority of the Commerce Clause. ${ }^{395}$ Like trademarks, the express language of the EEA invokes the authority of the Commerce Clause. ${ }^{396}$ The language of section 1832(a) states that a trade secret defendant must have the "intent to convert a trade secret, that is related to or included in a product that is produced for or placed in

391. Michael Maiello, Ten Markets Transformed by the Internet, FoRBEs (Oct. 25, 2007, 10:25 PM), http://www.forbes.com/2007/10/24/markets-transformed-internet-marketsmarketsp07-cx_mm_1025internet.html.

392. Id.

393. Id.

394. U.S. Const. art. I, $\$ 8$, cl. 8.

395. See U.S. Const. art. I, $\$ 8, \mathrm{cl}$. 3. The Commerce Clause states that Congress has the power "[t]o regulate Commerce with foreign Nations, and among the several States, and with the Indian Tribes." Id.

396. 18 U.S.C. $\$ 1832(a)(2006)$. 
interstate or foreign commerce." ${ }^{397}$ Just as trademark enforcement is established under the constitutional authority of the Commerce Clause, so too is trade secret protection by virtue of the EEA. ${ }^{398}$

The unification of state intellectual property law by means of federal preemption is not new. Just as trade secrets are currently subject to the laws of the states, trademark law also used to be subject to the laws of each state. When the Lanham Act ${ }^{399}$ was enacted in 1947, Congressman Fritz G. Lanham, the Act's sponsor, stated that "[t]he purpose of [the Act] is to protect legitimate business and the consumers of the country." 400 The Senate Report for the Lanham Act elaborated further by stating that the purpose of federalized trademark law serves two primary purposes. ${ }^{401}$ First, the federal trademark law was enacted "to protect the public so it may be confident that, in purchasing a product bearing a particular trade-mark which it favorably knows, it will get the product which it asks for and wants to get." ${ }^{\text {"02 }}$ The second goal is to protect the trademark's owner. This is accomplished ensuring that "where the owner of a trade-mark has spent energy, time, and money in presenting to the public the product, he is protected in his investment from its misappropriation by pirates and cheats." ${ }^{203}$ Thus, Congress's goal in passing trademark legislation was a dual one: to protect both the owner and the general public. ${ }^{404}$

One way of accomplishing this goal was to create uniform legal rights and remedies that were appropriate for a "national economy." congressional vote to federalize trademark law, Congress noted that trademark protection was "entirely a State matter," and the result of this piecemeal approach was that there were almost "as many different varieties of common law as there are States." ${ }^{\text {"06 }}$ Congress correctly observed that a person's right to a trademark "in one State may differ widely from the rights which [that person] enjoys in another." ${ }^{\text {"407 }}$ The House Committee on

397. Id.

398. Id.

399. See 15 U.S.C. $\$ \$ 1051-1129$ (2006).

400. 92 CONG. REC. 7524 (1946) (emphasis added).

401. S. REP. No. 1333, at 3 (1946), reprinted in 1947 U.S.C.C.A.N. 1275.

402. Id. (emphasis added).

403. Id. (emphasis added).

404. Id.

405. H.R. REP. No. 944, at 4 (1939).

406. Id.

407. Id. 
Trademarks and Patents, recognizing that "trade is no longer local, but ... national[,]" saw the need for "national legislation along national lines [to] secur[e] to the owners of trade-marks in interstate commerce definite rights." ${ }^{408}$

The purpose of a federal system of civil trade secret laws would mirror the purposes of the federal system of trademark law. First, its purpose would be to protect the general consumers. Consumers will be protected by virtue of the economic impact that the federal system could have on corporations, which produce goods or services that are used within interstate commerce. With the Fortune 1000 companies incurring $\$ 59$ billion in expenses annually as a result of trade secret misappropriation, ${ }^{409}$ there is no doubt that a federal system will help to ameliorate the associated financial burdens that arise as a result of trade secret protection and misappropriation. Second, its purpose also would be to benefit business owners through a federalized, uniform set of trade secret laws. With a uniform standard of laws established by Congress, each business owner will know what he needs to do to protect all of his intellectual property. A uniform system of laws will aid the business owner in understanding how properly to decide between a patent, a copyright, or a trade secret when seeking to protect his intellectual property. Also, a uniform approach will allow all American businesses the predictability and protection that the law is intended to afford American citizens.

\section{B. Implementation of Federalized System Under the EEA or a New Scheme}

Trade secret law is already partially included within the federal laws of the EEA. ${ }^{410}$ Under the current EEA, trade secrets are only enforced by means of criminal prosecution. ${ }^{411}$ A civil remedy is available under the EEA, but it is only available to provide an injunction as a concomitant effect of the criminal prosecution. ${ }^{42}$ To establish a proper system that will effectuate the goals of a uniform system of federal trade secret law, Congress should include provisions within the EEA that will precisely address the inconsistencies that are found within current trade secret law. Within the statutory language of the new system, it would prove helpful if Congress

408. Id.

409. Office of the National Counterintelligence Executive, supra note 335, at 1.

410. See 18 U.S.C. $\$ \$ 1831-1839$ (2006).

411. See id. \$\$1831-1832.

412. See id. $\$ 1836$. 
would expand the statute to maintain the current section of the EEA $\mathrm{A}^{413}$ and to also add a separate section that precisely addresses civil enforcement and provides for an array of civil remedies.

\section{Piercing the Reporter's Shield: Specialized Federal Provisions that Will Prevent Trade Secret Misappropriation Protection by Bloggers.}

Within this unified system, it would be helpful for Congress to include a provision that will expressly preempt any state's reporter's shield law when trade secret dissemination is at issue. An excellent example of how this could potentially function is found within the Texas reporter's shield laws where Texas has incorporated a reporter's shield statute expressly for civil actions and enacted a second reporter's shield statute that applies when criminal activity is implicated. ${ }^{414}$

Under the civil provision of Texas's journalist privilege, the statute offers the same privilege as nearly all state reporter's shield statutes-the immunity for the journalist not to reveal his source. ${ }^{415}$ Nevertheless, Texas has enacted a separate journalist shield statute that is only applicable when criminal activity is involved. ${ }^{416}$ Instead of providing one carte blanche provision that covers a journalist in either a civil or criminal case, this statute-focusing only on criminal actions-limits the efficacy of the shield under four circumstances. ${ }^{417}$ First, the shield does not apply if the journalist witnessed the source committing a felony. ${ }^{418}$ Second, the shield does not apply when the source has confessed or admitted to the reporter that he has committed a felony. ${ }^{419}$ Third, the shield does not apply when there is

413. Under a new uniform system, the criminal section of the EEA could be invoked when a defendant in bad faith forces a purchase upon a trade secret owner.

414. Compare TeX. Civ. PRAC. \& Rem. Code ANn. $\$ 22.021$ (West 2009) (Texas civil journalist's privilege), with TEX. CODE Crim. Proc. AnN. art. 38.11 (West 2009) (Texas criminal journalist's privilege).

415. See Tex. Civ. Prac. \& Rem. Code Ann. \$22.023 (West 2009).

416. TeX. Code Crim. Proc. ANN. art. 38.11 (West 2009).

417. Also within sections $1-3$, the entity seeking the information from the reporter must exercise "reasonable efforts" to procure the information from all other possible sources of the confidential information. Id. $\$ 4(a)(1)-(3)$. Under section 4, there may be disclosure in the absence of reasonable efforts only when disclosure is "reasonably necessary to stop or prevent reasonably certain death or substantial bodily harm." Id. $\$ 4(\mathrm{a})(4)$.

418. Id. $\$ 4(\mathrm{a})(1)$.

419. Id. $\$ 4(\mathrm{a})(2)$. 
probable cause to believe that the source participated in a felony offense. ${ }^{420}$ Fourth, the shield does not apply when the disclosure of the information is reasonably necessary to prevent the death or substantial bodily harm to a third party. ${ }^{421}$ Under all four of these circumstances, the Texas legislature has taken the reporter shield statute out of play, and defendants may not hide behind the shield but must reveal their confidential source.

Within a new federal trade secret law scheme, an express preemption clause to override any state reporter's shield statute would eliminate the problem presented in O'Grady v. Superior Court. ${ }^{422}$ This provision would effectively bar a party from refusing to reveal the source from which he received his confidential information. Specifically, Congress should maintain the second and third limitations, as expressed in the Texas journalist's privilege statute, when criminal activity is involved. ${ }^{423}$ The second limitation is that any journalist's shield protection will be dissolved when the source has confessed or admitted to committing the appropriation of a trade secret. ${ }^{424}$ The third limitation takes effect when there is probable cause to believe that the source has wrongfully obtained the trade secret information. ${ }^{425}$ Under both of these provisions, it is also required that the person seeking the information must take reasonable measures to obtain the information from other channels before the journalist's shield may be pierced. ${ }^{426}$ This provision of a uniform trade secret act will allow all trade secret owners to protect their trade secrets from the threat of destruction by way of dissemination through the Internet.

\section{CONCLUSION}

Congress should enact a uniform system of federal trade secret laws that will unify the currently divided topic of trade secret law. Under this new scheme, the uniform system should do the following: allow for a uniform definition of the reasonable measures necessary for trade secret protection, provide a uniform section either allowing or disallowing the inevitable

420. Id. $\$ 4(\mathrm{a})(3)$.

421. Id. $\$ 4(\mathrm{a})(4)$.

422. O'Grady v. Superior Court, 44 Cal. Rptr. 3d 72 (Cal. Ct. App. 2006).

423. The criminal activity that will allow for the piercing of the reporter's shield should include any felony crime-including a violation of the EEA.

424. See Tex. Code Crim. Proc. AnN. art. $38.11 \$ 4(a)(2)$ (West 2009).

425. See id. $\$ 4(\mathrm{a})(3)$.

426. Id. 
disclosure doctrine, enact a statutory provision that will preempt the use of a state's reporter's shield statute, and criminally prosecute trade secret defendants under the EEA far more frequently. This uniform system would help alleviate the rising costs and commercial theft that many of America's top companies face today. Most of all, the new test would aid the American public by reducing overall costs to corporations and would provide a structured and predictable framework that business owners need to effectively run their businesses. 